\title{
NEW TRENDS IN PENSION BENEFIT AND RETIREMENT PROVISIONS
}

\author{
Olivia S. Mitchell
}

Working Paper 7381

http://www.nber.org/papers/w7381

\section{NATIONAL BUREAU OF ECONOMIC RESEARCH 1050 Massachusetts Avenue \\ Cambridge, MA 02138 \\ October 1999}

Financial support for this research was provided by the Pension and Welfare Benefits Administration of the US Department of Labor; able research assistance was provided by Erica Dykes. Opinions are solely those of the author and not of the persons or institutions with which she is affiliated.

(C) 1999 by Olivia S. Mitchell. All rights reserved. Short sections of text, not to exceed two paragraphs, may be quoted without explicit permission provided that full credit, including $\mathbb{C}$ notice, is given to the source. 
New Trends in Pension Benefit

and Retirement Provisions

Olivia S. Mitchel

NBER Working Paper No. 7381

October 1999

JEL No. G2, J14, J33

\section{ABSTRACT}

This study illustrates and interprets changes in pension plan retirement formulas and benefit provisions over the last two decades, using extensive information on private sector pension plans gathered by the U.S. Department of Labor since 1980. Data generated from the Employee Benefits Survey (EBS) of medium and large firms shows that pension provisions have changed a great deal in companies that have traditionally been the most consistent providers of employer-sponsored retirement benefits in the US. In the defined benefit environment, vesting rules were loosened somewhat; plans have eased access to normal retirement; and pension benefit formulas have moved toward final rather than career earnings, with increased weight on straight-time pay. In addition, these plans became more integrated with social security, but the form of this integration has changed substantially. Defined benefit pension replacement rates appear to have fallen over time, though the time series is not complete. In addition, benefit caps remain in place, generally by limiting years of service in the formula; disability benefit provisions have also become more stringent; and it is increasingly possible to take a lump sum from one's defined benefit pension. The defined contribution environment has also seen substantial change, as documented in the BLS series. Participation and vesting rules appear most lenient for workers in $401(\mathrm{k})$ plans; most employees must contribute to their plans, generally as a function of earnings; and employee access to pension fund assets appears to be on the upswing over time. Participants in these plans have also gained access to diversified stock and bond funds, with fewer permitted to invest in own-employer stock, common stock funds and guaranteed insurance contracts. We conclude with a discussion of how future data collection efforts could be improved.

Olivia S. Mitchell

The Wharton School

3641 Locust Walk, Rm 307 CPC

Philadelphia PA 19104-6218

and NBER

mitchelo@wharton.upenn.edu 


\title{
New Trends in Pension Benefit and Retirement Provisions
}

\author{
Olivia S. Mitchell \\ with the assistance of Erica L. Dykes
}

The last twenty years has brought about a substantial transformation in the US private pension environment. Employee interest in pension programs has grown as a result of the aging of the baby boom, as workers began to demand retirement savings, and as the stock market has made retirement saving an appealing (and a tax-preferred) way to invest in equities. In addition, rising life expectancies and longer worklives made the pension promise more valuable to groups that had traditionally lacked pensions, especially women. ${ }^{1}$ Employers, too, were willing and even eager to supply new forms of pensions, responding to the need to downsize their workforces, to changes in the industrial and occupational mix of employment, and to an interest in using pensions to induce particular worker behaviors. ${ }^{2}$ The regulatory environment also changed in the last two decades, as tax reform has imposed stricter limits on funding levels, contribution amounts, and benefit payouts (McGill et al, 1996). In sum, the last two decades proved conducive to pension growth and development along some dimensions, but also turned out to be a time of substantial challenge to both those wanting and supplying pensions in America (Sass, 1997).

In the present report, we highlight and evaluate some of the most important changes observed in US private sector pension plan retirement formulas and benefit provisions during the two decades of the 1980s and the 1990s. To learn more about trends in pension provisions and formulas over time, we have gathered, tabulated, and interpreted information provided in a series of reports published by the U.S. Bureau of Labor Statistics (BLS) over the last two

\footnotetext{
${ }^{1}$ For a discussion of the role of pensions in women's retirement income see Levine, Mitchell and Phillips (1999).

${ }^{2}$ For a discussion of these and other effects see the studies reviewed in Gustman et al (1994, 1995), Ippolito (1986), and Mitchell (forthcoming).
} 
decades on pensions offered by medium and large firms. Over the period between the early 1980's and the mid-1990's, the BLS tabulated and published individualyear summaries of information from its Employee Benefits Survey (EBS). In the present study we have collected these data as well as additional unpublished tabulations for 1997 generously supplied by the BLS. ${ }^{3}$ In doing so we update our previous study (Mitchell, 1992) which explored changes in pension provisions through 1988. In the present report, where possible, we extend the time series by relying on published tables to 1995 along with unpublished reports for 1997. There are no more recent data publicly available for this purpose.

The plan of the paper is as follows. We begin with a discussion of retirement plan features, particularly focusing on benefit formulas. Next, we analyze trends in retirement provisions and benefit formulas found in defined benefit and defined contribution plans over time. We conclude with a summary of findings.

\section{Overview of Pension Type and Pension Features ${ }^{4}$}

In the US corporate or private sector pensions may be classified onto two general types: defined contribution and defined benefit plans. ${ }^{5}$ In the defined contribution (DC) pension, a covered employee often has a choice as to whether to participate in the plan, and if so, how much to contribute. In addition, the plan sponsor often adds to the pension fund on behalf of participating employees based on some match of employee contributions. Contributed funds are then invested in the capital market; a participant often has choice over investment options into which his own - and sometimes his employer's - funds are deposited.

\footnotetext{
${ }^{3}$ We thank Ann Foster of the BLS for assistance obtaining these data.

4 This discussion builds on Mitchell (1992).

${ }^{5}$ Cash balance plans are sometimes seen as a third type of plan, in that they seem to combine elements of both DB and DC pensions. However they are, strictly speaking, defined benefit plans because the plan sponsor guarantees the promised rate of return on participant assets (Rappaport et al., 1998). In any event, thus far the BLS has not generated special tabulations for cash balance or hybrid plans.
} 
Usually, the contributions and earnings on the investments must be preserved for retirement, but sometimes an active worker may access his funds for hardship or some other purpose. On leaving the firm, the departing worker may receive his accrual in the form of a lump sum (thought receipt of the lump sum may trigger a tax penalty unless he is at least age 59.5); alternatively the departing worker may take his pension benefits in the form of a periodic amount or buy a life annuity. The value of the plan accrual at any given date depends on amounts contributed and investment returns earned on these, over the entire worklife. By contrast, a worker with a defined benefit (DB) plan receives a promise of an eventual pension benefit that is determined by a pre-specified formula. Here the replacement rate (defined benefit as a percent of pre-retirement pay) is typically a function of the covered worker's age, pay, and/or service levels. In most cases the defined benefit is payable as a life annuity though in some cases the benefit may be accessed as a lump sum.

As we shall show below, both pension plan types embody a range of eligibility, contribution, vesting, benefit, withdrawal, and retirement provisions and formulas. In addition, there are myriad special provisions regarding postretirement benefit increases, provisions for special payouts (e.g. disability or lump sum cashouts), and other features. It is our goal in this investigation to determine how, if at all, pension plans of medium and large firms in the private sector have changed over the last two decades, to determine whether any salient trends deserve attention.

Understanding how pension provisions and benefit entitlements have changed over the last two decades is important for several reasons. It is well known that many pension provisions powerfully affect the nature of the pension promise, and in turn they influence worker and firm behavior (c.f., Gustman and Mitchell 1992; Gustman et al 1994 and 1995). For instance, a pension-covered employee allowed to take a loan or a lump-sum cashout from his plan after a short vesting period gains access to his pension saving early the worklife, a practice that some worry will fail to protect him in old age. The employee 
prohibited from taking a loan or cashing out the pension accrual lacks access to the accrued pension, and he may end up with a better-funded retirement period than his counterpart. These and other structural features of pensions also influence worker turnover patterns. That is, vesting and benefit formulas can deter mobility for younger employees, and they can also induce workers to remain on the job longer if the plan offers substantial rewards for continued work (c.f., Fields and Mitchell 1984). Other times, as in the case of defined contribution pensions, retirement benefits may depend on amounts contributed and how the worker chose to invest his pension assets. It has been shown that investment decisions depend to a large degree on how successful employers are in communicating benefit plan attributes to employees (Mitchell and Schieber, 1998).

Before turning to a more detailed discussion of pension trends in the EBS, it is useful to briefly review key pension terminology and the importance of specific pension provisions.

Plan Participation and Vesting. Workers covered by a private pension are often not permitted to join their pension plan immediately; rather many plans limit participation to workers who remain at the firm more than one year, and sometimes also limit coverage to those over the age of 21. The Employee Retirement Income Security Act [ERISA] of 1974, as amended, mandated that plan participation requirements could not be more stringent that this, but plans may be more generous. What is meant by 'plan participation' matters, of course, since some pensions begin to count years of service for benefit purposes from the date that the worker becomes a plan participant. 'Vesting' in a pension plan is important since it refers to the juncture at which the worker gains a legal claim to an eventual benefit from a pension plan in which he is a participant. Many firms do not offer new workers an immediate right to a benefit; rather, the firm will specify that workers gain this legal claim only when they meet employment criteria specified in the plan's vesting formula. This is often expressed in terms of minimum age and/or years of service required to gain a legal claim over a 
retirement benefit. In 1974, ERISA spelled out a series of legally permissible vesting schedules including the very common "10-year cliff vesting rule", which required a worker to be vested after 10 years of service. Vesting standards were subsequently eased under the Tax-Reform Act of 1986, with most plans now using a "5-year rule" for cliff vesting.

Retirement Eligibility Requirements. Most pension plans require that a covered employee must complete a requisite number of years of service and/or attain a specified age, in order to receive a pension annuity payment. Thus, for instance, a worker may be eligible for early retirement at age 55 with 10 years of service, while normal retirement might be defined as leaving at age 65 with at least 10 years of service.

Such plan-based age and service requirements are common in both DB and DC plans, and they are important because these establish conditions under which the worker can claim plan benefits. However eligibility requirements play a crucial role in DB plans, since age and service directly affect the level of benefits a retiree may receive. This is because defined benefit plans often adapt payments based on the retiree's age and/or service at the worker's departure date. For instance, an early retiree might receive a lower annual benefit amount that the one payable at the plan's normal retirement age. The higher benefit for normal retirement is reflective of the fact that at a later age, a worker has more years of service, possibly a higher pay lever, and fewer years of life remaining over which to draw a benefit. In addition, defined benefit plans frequently structure their benefit formulas so as to subsidize early retirement (c.f., Fields and Mitchell 1984). Hence retirement requirements are important insofar as they establish when a worker may begin to receive subsidized early payouts.

For many years, corporate sponsors in the US were permitted to use their pension formulas to induce older workers to leave their jobs, mainly by limiting pension accruals after a specific age (Luzadis and Mitchell 1998). But in an effort to reduce the extent of age discrimination, the Omnibus Reconciliation Act of 1986 required private-sector pensions to continue benefit accruals after normal 
retirement, a ruling that took effect for most private sector pensions in 1988 . (Collectively bargained plans were permitted somewhat longer to come into compliance.) Hence retirement eligibility rules for private sector pension plans have become more liberal over time, somewhat increasing benefit incentives to remain employed at older ages.

Retirement Contribution and Benefit Provisions.

Defined Benefit Plans: Defined benefit plans use many different methods to compute participants' payouts at retirement. Some pension benefit formulas provide for flat dollar amount entitlements, while others base benefits on employee pay, age, and/or service at retirement. If pension benefits depend on earnings, the employer generally specifies what percentage of earnings will be paid per year of service. A related issue is that earnings-based plans differ in terms of which definition of earnings they consider relevant. For instance, straight-time pay alone may be considered, or a plan may add overtime, shift pay, and/or commissions into the formula. In addition, pay-based plans differ in terms of the period of time over which earnings are computed. In a career earnings plan, pay during the entire period of employment is considered; conversely, a terminal earnings plan focuses on compensation just prior to retirement. Even terminal earnings benefit formulas generally include more than the final year's pay in the formula; it is not uncommon to use the worker's highest or last 5 years as the basis fore a final average pay figure.

In some cases pension formulas are integrated with social security rules following one of two general patterns. ${ }^{6}$ "Offset" formulas typically reduce a pension benefit payment by some fraction of the worker's primary social security amount, while an "excess" plan will apply lower pension benefit accruals to earnings below the social security taxable wage base (or some similar threshold) and higher benefit accumulations to earnings above this amount. Terminal earnings plans tend to use the offset approach when they are integrated, while

\footnotetext{
${ }^{6}$ For a more complete discussion of integration with Social Security see McGill et al (1996).
} 
career earnings plans tend to sue the excess method. Integration is less common in plans using flat dollar amounts.

Defined benefit pension plans have various other special benefit rules, many of which affect retirement benefits under certain conditions. The BLS has gathered information over time on benefit reduction factors, important in determining the rate at which annual benefit payments are reduced for workers retiring early. These reduction factors often turn out to encourage early retirement, because they reduce early retirement pension payments often to prove to be larger than the normal retirement benefits in present value terms, providing a pension subsidy for early retirement. Trends in these are examined in the next section.

Other aspects of defined benefit plans may also be developed using the BLS tabulations, though unfortunately these have not all been carried out in a continuous way over all years and some important series are no longer provided. One of particular interest is the time series on average replacement rates for employees of varying pay and service levels, indicating how retirement pensions compare to pay levels just prior to retirement. These tabulations indicate the extent to which pensions have risen relative to final pay. In addition benefit maximums are indicated, usually as a function of service and/or pay. Many plans also offer pension increases after retirement, in partial recognition of the declining purchasing power of benefits fixed in nominal terms. Though most private-sector pensions do not formally index benefit payouts, ad hoc increases have been implemented in inflationary times, contributing to increased economic security in retirement (Allen et al. 1986).

Another feature of interest to pension experts is data on workers' access to pension accruals for special reasons, including for early receipt of vested benefits and for disability. When workers have access to vested accrued benefits, they sometimes fail to save the accumulations for retirement, a subject of much policy debate (Fernandez, 1992). Disability pensions are another way in which workers can receive benefits prior to becoming qualified for a regular pension, which also plays a role in increasing economic security. 
Defined Contribution Plans: The institutional structure of defined contribution plans is as varied as among their defined benefit counterparts, but along different dimensions. Many different types of plans exist, categorized according to various classification schemes. In the past, the BLS distinguished between plans it called "retirement" plans, versus those called "capital accumulation" plans; the former generally prohibited withdrawal of pension accruals prior to retirement, and the later afforded easier access to plan assets. But over time, it has become clear - and the BLS has recognized - that "most defined contribution plans can be used to provide retirement income or to accumulate financial assets" (US DOL, 1989, p.107). In addition, many of these plans allow lump-sum cashouts rather than a benefit annuity. Of course several new plan types have also gained in importance during the late 1980's and thereafter. For this reason the BLS tabulations now distinguish types of defined contribution plans according to the source of their finances, or to the way in which their assets are held. Examples include savings and thrift plans, profit-sharing programs, money purchase pension plans, employee stock ownership/stock bonus plans, and 401(k) plans. Savings and thrift plans are those where workers contribute a percentage of their pay and employers generally offer some amount of matching contribution (perhaps up to a maximum). The tax treatment of employee contributions depends on both individual plan structure and overall tax code limitations on the amount of compensation that can be tax deferred. Savings and thrift plans often permit workers to borrow from or make taxable withdrawals from their plans in special circumstances (e.g., educational or medical expenses). Profit sharing plans offering deferred income tend to link employer contribution levels to company profits, and then allocate the employer contribution levels to company profits, and then allocate to employer contribution based on workers' pay or other formulas. Early withdrawals or loans are rather less common here than in other plans. In a money purchase plan, employer contributions are fixed, usually as a fraction of earnings, whereas in stock ownership and stock bonus plans the employer contributions are usually in the form of company stock. And from the 
late 1980's on, 401(k) pensions have grown quite rapidly. The BLS has sought to adapt the EBS by following changes in plan type, tracking not only profit sharing and savings/thrift plans but in more recent years adding series on 401(k) plans as well. Here the time series are necessarily shorter than for defined benefit provisions.

\section{Changes in Pension Plans: 1980-1997}

Tabulations of Employee Benefits Survey (EBS) data on pensions by the Bureau of Labor Statistics are presented in two separate segments, one linked to DB plans and the other to DC plans. Each is taken up in turn, with reference to the relevant tables we have collected for our purposes, which appear at the end of the report. We note that the BLS did not present identical tabulations in all years, producing some inconsistencies in the reporting (see the Appendix). In addition some series stop being reported toward the late 1980's, while others were developed for the first time during the early 1990's. This change in format and coverage makes it difficult and in some cases impossible to develop and interpret some interesting hypotheses regarding pension trends.

Defined Benefit Plans. Time series EBS data are available on three important characteristics of defined benefit pension plans: (1) participation, eligibility and vesting; (2) withdrawal and benefit formulas, and (3) special provisions. Trends in each are examined in turn.

Participation, Eligibility and Vesting. Defined benefit pension plans typically specify criteria that covered employees must meet before becoming full-fledged pension participants. Such requirements are justified by the need to reduce administrative costs that would otherwise be incurred for young workers. The effect of these participation requirements is thought to be a reduction in turnover by offering workers an incentive to remain with the company (Gustman and Mitchell, 1992). Under the Employee Retirement Income Security Act (ERISA) of 1974, full-time employees age 25 or older must be granted participant status 
after completing 1 year of service. Participation rules were subsequently amended by the 1984 Retirement Equity Act (REA), which for most plans lowered the participation requirement to age 21 as of mid-1986.

The EBS information on plan participation requirements (Table 1) indicates that there was a steady increase in the fraction of full-time employees covered by DB plans having a minimum age and/or service requirement, over the period 1981-1997. For the DB plan participants examined in 1981, 59\% had minimum age and/or service requirements; the fraction grew to $68 \%$ by 1997 . About half of the plans require only 1 year service, with the other half covered by the "age 21/service 1" rule imposed by the REA. Virtually no plan has an "age only" criterion. The pattern is therefore consistent with the notion that the law change (REA) was successful in bringing about earlier participation for many workers, but the drop in the fraction of workers permitted to participate in their plans immediately seems to have worked in the opposite direction.

Also appearing in Table 1 is information on a practice permitted by ERISA until 1988, namely the imposition of participation limits if a worker joined a firm within 5 years of the pension plan's normal retirement age. During the 1980s this practice permitted firms to hire older workers without incurring large pension obligations, and as of $1981-2$, some $60 \%$ of covered workers were in plans of this type. But the 1986 Omnibus Reconciliation Act (OBRA) eliminated maximum age restrictions from 1988 onward, by which year the fraction dropped slightly, to $47 \%$. The BLS did not tabulate comparable data thereafter, but the pension change brought about by OBRA likely increased employment costs for firms hiring older workers near the plan's retirement age.

Once a worker becomes a DB plan participant, he must typically satisfy a plan service requirement before gaining a legal vested right to the plan. Economists have argued that these vesting requirements serve to deter worker turnover, inasmuch as vesting guarantees and eventual retirement benefits would otherwise be lost if a worker changed employers (c.f., Gustman and Mitchell 1992; Gustman et al. 1994 and 1995). In 1974 the Employee Retirement 
Income Security Act (ERISA) specified a number of permissible vesting formulas including a "10-year cliff" rule requiring an employee to participate in the plan for a decade, before becoming 100\% vested. Subsequently, the 1986 Tax Reform Act (TRA) required single-employer plans to convert to a 5-year schedule if using cliff vesting (or 7 years if graded vesting was in place); the 5-year approach was adopted by most plans by 1989. Table 2 shows that the fraction of DB plan participants with cliff vesting rose over time from $89 \%$ to $96 \%$, but the modal number of years until vesting fell from 10 to 5 between 1988 and 1989, consistent with the legal requirement. Graduated vesting schedules give an employee a right to a gradually increasing share of accrued benefits, eventually reaching $100 \%$ at a specified age and/or service point. Graduated vesting schedules covered about $11 \%$ of all DB participants in 1980 , rose to $17 \%$ in the late 1980 's, and then fell to $3 \%$ by 1997 . Overall, vesting requirements in DB plans have definitely eased over last two decades.

Contributions. Turning to contributions, the evidence shows that most private sector DB plan participants are rarely required to contribute to their pensions out of own salary or earnings. This question has only been tracked since 1993, but the evidence shows that only $3-5 \%$ of participants have employee contributions required (Table 3). ${ }^{7}$

Withdrawal and Benefit Formulas. We focus next on conditions under which participants can access the funds in their pension accounts. DB plans generally specify minimum age and/or service criteria that a worker can must satisfy in order to retire and receive "early" benefits. The relevant trends are reported in Table 4, and the data show that early retirement was and has remained the norm in the DB environment, with $95 \%$ or more having this in their plans since 1980. But the fact that early retirement is generally available obscures changes in requirements for collecting early benefits. It does appear that earlier retirement has become somewhat more accessible over time: in 1982, 60\% of all participants 
could leave at age 55 (in some cases, depending on service), and by 1995 this fraction stood at $66 \%$. But the trends are not uniform: in the late 1980's there was a peak in the fraction of workers permitted to leave at age 55 with 10 years of service, but this practice appeared to fall during the 1990s. Conversely it became much easier to retire with only 5 years of service at age 5 , with the fraction in this group rising from 3\% to $20 \%$ between 1980 and 1997. It is interesting that relatively few participants (5\%) were in plans where they had to satisfy only an "age plus service" requirement in 1980; the practice increased slightly (to 10\%) by 1985, and then declined again (to 8\%) by 1997 .

Turning to "normal" retirement requirements, most DB plans require retirees to meet certain age requirements, or alternatively age plus service (Table 5). Only $11 \%$ of DB plan participants in 1980 could obtain normal retirement by virtue of service alone, and 30 years was the typical cutoff; by 1997 fewer than half this many (5\%) of the participants could take normal benefits based on service alone. Just under half of all participants were subject to normal retirement eligibility rules that only depended on age in 1980, with fraction remaining fairly stable over the entire period. Where age only serves as the criterion for normal retirement, age 65 has traditionally been the modal age. During the late 1980s there was a small increase in early retirement age requirements at 62 and 60, but the trend appeared to have reversed by 1997 . Turning to requirements involving both age plus service, it appears there has been an increase in the propensity of participants to have normal retirement available at age 62 with a combination of years of service. In 1981, 17\% of the participants were able to retire at 62 with full benefits ( $4 \%$ at 62 with no service plus $13 \%$ with some service); by 1997 this fraction had risen to $21 \%$ (3\% and 18 respectively). In other words there appears to be a continued trend toward permitting workers to before age 65 and receive full (unreduced) benefits. These patterns are in line with findings from other studies indicating that many pension plans have encouraged earlier retirement over time (Luzadis and 
Mitchell, 1991; Mitchell and Luzadis, 1988). Whether this pattern will persist into the tight labor markets projected for the next 20 years remains to be seen.

Benefit formulas are described in Table 6 where we see that the fraction of DB plan participants with benefits based on a flat dollar amount fell from $30 \%$ in 1980 , to $23 \%$ by 1997 . This decline may be due to the steady drop in the unionization rate of the US workforce, since flat dollar benefits were often associated with collective bargaining agreements. Instead, most DB plans surveyed in the 1990s used workers' earnings to determine benefit amounts. This fraction stood at around 2/3 of all participants in 1997, virtually the same as in 1980. It is not surprising that terminal earnings are by far the most common in benefit formulas, since this approach is believed to protect retirement promises from inflation, at least to the extent that pre-retirement pay tracks inflation. The fraction using this approach varied around the 55-58\% level throughout the period. By contrast, only $11 \%$ of all DB participants still had benefits computed using career earnings in 1997, down from 15\% in 1980. Each of these changes somewhat reduces the risk of inflation that the workers bear in their prospective pension payments, by linking benefits to pay during the final years of the work career. In addition, terminal earnings plans tie retirement benefits more closely to individual performance toward the end of the worklife, as compared to the previously more-popular career average plans.

In addition to knowing what years of earnings are included in the formula, it is of interest to investigate what pay definition is used. Table 7 indicates that there has been a marked increase in the fraction of workers receiving benefits based on straight-time or base pay alone, from $44 \%$ to $62 \%$ in just the eight years between 1988 and 1995 (data for other years are not available). And fewer DB plans now include other forms of pay including shift differentials, bonuses, and commissions, signaling a reduction in the incentive-based portion of pensions as compared to earlier years. Limiting the full range of compensation used in computing benefits may make it easier for workers to remain employed at older ages, despite possible changes in productivity. 
Defined benefit plans generally allocate benefits according to some percent per year of service or pay, and these fractional benefit rules are summarized in Tables 8 and 9. For career earnings plans, only about one-third of all participants in 1991 were covered by a plan with a flat percent per year of service, with the most common percentage being $1.25-1.75 \%$ of pay (the data were not tabulated for the more recent years; see Table 8). By contrast, some $60 \%$ of participants were in plans paying benefits where the fraction of pay varied by year of service, with the modal pattern being a fraction varying by earnings. For terminal earnings plans, Table 9 shows that most plans used five years' pay, with five consecutive years being the most common approach. Nevertheless, there was a small increase in the prevalence of plans using three instead of five years of pay, rising from $14 \%$ to $17 \%$ over the period 1983-1997. More confounding is the inverted U-shaped pattern in the fraction of pay used in benefit formulas: early in the $1980 \mathrm{~s}, 47 \%$ of the participants had benefits that were a flat percent per year of service (with the norm being in the range of 1.25-1.5\%). Then the fraction of participants using a flat percent per year of service in the benefit formula rose slightly, to $54 \%$ by the late 1980 s, and subsequently it fell to $35 \%$ by the late 1990s. By contrast, over time plans were more likely to employ benefit percentages that depended on other factors, with the fraction depending on earnings rising and on service falling. Finally, Table 10 provides tabulations on the prevalence of dollar amount formulas over time. Here it is clear that the plans using dollar amounts tended to increase those amounts over time, with the modal factor now being over $\$ 30$ per year of service. Of course, it will be recalled that few plans are in this latter group.

Benefits paid by DB plans depend not only on earnings or service-based formulas; in addition, retiree payments are frequently integrated with Social Security benefits. Table 11 shows that $45 \%$ of DB plan participants had their benefits integrated with Social Security in 1980, and though the integration fraction crept up to 63\% by 1989, it fell back again by 1997 (to 49\%). What is interesting is that this overall pattern hides major changes in the way 
integration has been handled over time. Specifically, between 1980 and 1997, there was a halving of the fraction of workers with benefits offset by Social Security payments where the fraction fell from $30 \%$ to $13 \%$; what grew instead was the prevalence of plans with excess formulas. In the latter case, a DB formula might provide $1 \%$ of pay up to the Social Security earnings threshold per year of service, for example, with some higher fraction (such as 1.5\%) for pay above this level. So while there is no overall change in the degree of Social Security integration in the Employee Benefits Survey, the type of integration used has actually changed substantially. It is of interest to recognize that these changes in pension integration practices coincide with large Social Security payroll tax increases; though a casual relationship cannot be proven in the data, the correlation is striking.

For those who retire early, benefits are often reduced in DB plans in recognition of the fact that early retirees will receive benefits for a longer period of time. Table 12 summarizes trends in early retirement reduction factors, and the evidence indicates that that many plans subsidize early retirement quite substantially. This may be concluded since in both 1982 and 1997, one-quarter of all DB participants were covered by early retirement reduction factors of $6 \%$ or smaller; it is often held that a reduction of more than 6 percent is required for actuarial neutrality (McGill 1996). ${ }^{8}$ Reduction factors are also applied to vested workers who leave their employers; here too, it appears that vested terminated workers face benefit reductions of $6 \%$ or less (but only three years of data are provided making it difficult to confirm the trend). The final panel of Table 12 shows that at least $90 \%$ of plans permit vested terminated workers to take their benefits prior to normal retirement, but only about half face the same reduction as applied to early retirees.

Benefit formulas are often quite complex to interpret, and for many years, the BLS provided a useful set of tabulations that could be used to compare

\footnotetext{
${ }^{8}$ Early retirement may also be subsidized in other plans using factors that vary with age and service, but this cannot be determined from available tabulations.
} 
retirement benefits for different hypothetical workers in the set of DB pensions under study. The technique adopted involved using plan information to compute "replacement rates", defined here as the ratio of the DB retirement plan benefits to the worker's final year of earnings. These computations were published for the period 1984-1993, calculated at the normal retirement age using six standardized pay levels and three seniority profiles (see Table 13). Unfortunately the agency ceased publishing these computations after 1993, which makes extrapolation beyond that date impossible.

In any event, Table 13 indicates that DB plan replacement rates typically rise with service for a given pay level; they follow this pattern both within a year and also over the period 1984 -1991. In 1993, however, the computed replacement rates fell across the board, and no computations were published in subsequent years. Comparing replacement patterns within service categories, it appears that these DB plan benefit formulas were fairly redistributive: that is, replacement rates were higher for the lower paid, and fell as pay rose for a given level of service. For instance, in 1993, the latest year reported, the replacement rate for a 30 -year worker earning $\$ 15,000$ was $27 \%$, and only $21 \%$ for a $\$ 65,000$ per year worker. We note that the "illustrative" pay levels reflected in the Table are not comparable in real terms, since a constant nominal earnings assumption implies a falling real pay level over time. As a very rough correction, one can compare replacement rates for a $\$ 25,000$ worker in 1984 with those of a $\$ 30,000$ level in 1989 , and these with that of a $\$ 35,000$ worker in 1993 . This simple approach suggests that pension replacement rates have been fairly constant over time; that is, holding constant real pay levels, benefit replacement rates for 10, 20, and 30 years of service changed relatively little over the years with the exception of the final year tabulated (1993).

Special Provisions in DB Plans. In the private sector, few pensions are protected against inflation by formal indexation; as a rule, private pension benefits are usually delivered as fixed nominal annuities. This is not a major concern for many older workers and retirees during low-inflation periods such as the present, 
but even a low inflation rate can cut a retiree's consumption in half in old age. In any event, Table 14 indicates that pension benefits are rarely tied explicitly to a cost of living index (COLA); indeed in 1995 only 7\% of EBS participants had a COLA, and only $3 \%$ had an automatic escalator. Quite frequently benefits are not increased at all, as can be seen by the fact that only $4 \%$ of the participants had plans with discretionary benefit increases in 1995. This is quite extraordinary given the generally strong equity market performance experienced by most of these plans during the 1980s and 1990s, but it is usually explained by the low inflation rates of the period.

In addition to these other benefit provisions, private pensions frequently impose a ceiling on benefit amounts payable to retirees. The prevalence of this phenomenon has been declining as is evident from Table 15. In 1984, for instance, $42 \%$ of the participants faced a benefit maximum; by 1997 , only $33 \%$ were capped. In plans that did limit benefits, they tended to do so by capping the number of years of service that can be counted for benefit purposes. In 1997, for instance $31 \%$ of the DB participants faced a maximum limit on service years. The modal choice for a maximum has generally been between 30 and 39 years of service since 1984 .

In addition to early and normal retirement, the vast majority of DB plan participants - three-quarters, in 1997 - is also covered by plans that will pay disability benefits (Table 16). The prevalence of disability pensions seems to have changed however in 1989, where coverage fell from near $90 \%$, to a much lower $81 \%$ and dropped further thereafter. It is not entirely clear why this sudden drop occurred, followed by an additional slide, though there were other changes taking place in the market for disability insurance driving employers to contain costs along many fronts. Indeed it appears that many DB plans tightened access to disability benefits over the period, by requiring that employees wait a longer time to qualify for long term disability insurance: only $46 \%$ was eligible for immediate disability benefits in 1997, down from a high of $70 \%$ in 1980 . Other features were also reduced in generosity after a run-up in benefits observed 
during the late 1980's, with companies being far less likely to credit service to retirement, and less likely to give unreduced normal benefits to the disabled employee.

A final DB payout issue is depicted in Table 17, which describes the prevalence of employer willingness to permit participants to take their benefits as lump sums at retirement. Initially this was unheard of in DB plans, and even in 1991 when these data were first tabulated, only $14 \%$ of participants could take any lump sum (about two-thirds of these could take the entire amount). By 1997, $23 \%$ of participants was permitted to take a lump sum, with the overwhelming majority entitled to take all of it in a lump sum. This trend underscores other evidence indicating the decline of annuitization among American workers (Mitchell, Poterba, Warshawsky, Brown, forthcoming).

Defined Contribution Plans. In turning to DC pension plans, we can draw on published evidence on (1) coverage and vesting patterns, (2) contributions and withdrawals, and (3) special features of 401(k) plans. We note that defined contribution plans experienced a rapid growth in popularity over the last two decades, and so consequently the BLS tabulations for this set of plans has changed in response to innovations in both plan type and plan design. As a result, BLS published information for DC plans is of more recent vintage and in some cases less continuos over time than the extensive BLS information on DB plans. In most cases, for instance, there is not complete data for the entire period 1980-1997; rather the data tend to be clustered around more recent survey dates. Plan Types, Coverage, and Vesting. The BLS has traditionally examined data on several types of DC plans including retirement and capital accumulation plans; these encompass money purchase and profit sharing, saving and thrift, and cash and deferred salary reduction plans including 401(k)s. Data are available on many of these only from 1985 on, since previously the BLS did not tabulate plan participation and design features for DC pensions in a comparable format. The 
time series are also often incomplete, since in many cases they end in 1991 due to changes in BLS reporting.

Statistics on participation in retirement and capital accumulation plans appear in Table 18. The BLS defines "retirement" plans as those where employer contributions are required to remain in the participant's account until retirement, death, disability, termination, hardship, or attainment of age $59 \frac{1}{2}$; by contrast "capital accumulation" plans are those where a participant may withdraw the money under other circumstances. The overall decline in coverage is unmistakable over the short period for which data are reported: noncoverage rose from $8 \%$ to $21 \%$ between 1985 and 1991 . While the fraction having only retirement plans dropped slightly, the proportion with both types of plans fell from $20 \%$ to under $10 \%$ in just six years.

Combinations of DB and DC plans appear in Table 19. One striking change evident in this table is the substantial drop in DB plan coverage, from $89 \%$ of the medium and large firm employees in 1985 , to half (50\%) in 1997 . A second fact is that the fraction of DB-covered workers with no other plan type appears to be growing, from $45 \%$ in 1985 to $55 \%$ by 1997 . Of those that have both a DB and a DC plan, the most prevalent DC type is a savings/thrift plan - almost one-third of all DB participants also had a DC benefit plan available to them in 1993 (more recent data are not provided). Another striking change is in the rapid overall growth of savings/thrift plans, where full-time worker coverage rates jumped from only 1\% in 1985 to $29 \%$ coverage in 1991. Cash or deferred salary plans also grew in prevalence, with $26 \%$ of full-time employees having either type in 1985 , and $45 \%$ by 1995 . A slightly longer time series appears in Table 21 , where it is clear that relatively few workers now have profit sharing plans; the fraction declined from a high of $22 \%$ in 1986 down to $13 \%$ in 1997. Stock and stock bonus plans are apparently quite rare, and there has been no long-term growth in profit sharing plans. Overall, the findings reinforce conclusions from other data sources indicating that the US workforce has increased its 
participation in DC plans but reduced DB plan coverage (Piascentini and Cerino 1990, Turner and Beller, 1989).

Age and service requirements for DC plan participation and vesting are given in Tables 22 and 23. Comparing the three DC plan types for which data are available - savings/thrift plans, profit sharing, and 401(k) plans - it is clear that participation requirements differ substantially. In the first two cases, the plans generally require minimum age and/or service for participation, with only around $15 \%$ of the workers were permitted immediate participation. By contrast, $27 \%$ of the $401(\mathrm{k})$ plan participants were allowed immediate participation. In all three instances, if a participation clause was in place, service of up to 1 year was the norm; relatively few plans also have an age requirement.

Vesting rules for all three DC plans are reported in Table 23, and show first a loosening in vesting rules, followed by a tightening thereafter. An inverted U-shaped pattern is evident for savings/thrift and profit shaving plans, with the fraction allowing immediate full vesting rising from the 20-percentile range to the high 30 s and even $40 \%$ by 1991 , then falling back to the 20 s by 1997 . The time series is shorter for $401(\mathrm{k})$ plans but indicates that more of the participants $-34 \%$ - could vest immediately on joining the plan. This contrasts with data presented earlier on DB plans, where virtually no employees had full and immediate vesting. Among those unable to vest in their DC plans immediately, participants appeared to be evenly split between cliff and graduated vesting. For instance in 401(k) plans, by the 1997 survey, cliff vesting (typically at 5 years) and graduated vesting (with two-thirds vesting at 5 years or later) were the norm for those without immediate full vesting. The trend to shorter cliff vesting is in part a result of the 1986 Tax Reform Act requiring most plans using cliff vesting to convert to a 5-year schedule as of 1989 . 
Contribution and Pre-retirement Access Patterns. Published tabulations of EBS include data on employee and employer contributions, as well as conditions under which employees can access these contributions prior to retirement.

Rules for employee contributions in savings/thrift and 401(k) plans are summarized in Table 24, with the vast majority of participants having plans that base employee contributions on workers' earnings - almost $90 \%$ in 1997 for both plan types. Most employees are now allowed to deposit their funds into the savings/thrift plans pre-tax, a substantial increase from 1985 (similar data for 401(k) plans are not available). Over the period, there appears to have been a gradual decline in the extent of earnings-based contributions - a 10\% decline in the case of the former plan type. Additionally the maximum fraction of earnings that can be contributed has been reduced over time, with fewer workers being allowed to deposit more than 15\% of their pay over the 1985-1997 timespan.

Evidence on employer matching contributions is summarized in Table 25 for the period 1985-1991 (more recent data are unavailable). Results show that almost no covered employees had firms that provided a specified dollar amount (1\% in 1991). Most employers match worker contributions with the modal match being $6 \%$ of pay; most plans ( $86 \%$ in 1993) had contributions of $6 \%$ or less, and only a minority (15\%) of covered employees had match rates of $7 \%$ or greater. In general, it appears that employer matching contributions averaged a much smaller fraction of earnings than employee contributions, and the rate of employer match seems to be falling over time. Employer contribution patterns for profit sharing plans appear in Table 26 , indicating that around $60 \%$ of those with this plan type use fixed formulas - with a most depending on profits (either as a fixed or variable fraction of profits). The remaining $40 \%$ use no fixed formula in determining contributions. When it comes to allocation of profits, there has been a decline over time in the practice of allocating profits according to earnings, with "other" formulas rising in importance.

One area that is of substantial interest has to do with time trends in the ways that employees are allowed to access their accounts, either before or after 
leaving their firms. The practice of allowing loans from employee accounts appears to be on the upswing in profit sharing plans (Table 26), with just a quarter of covered employees having this access in 1986, and almost a third permitted this access by 1997. A very different pattern appears in Table 27A describing conditions under which employees are permitted to withdraw pension assets in the event of hardship or other circumstances in saving/thrift plans (e.g., at termination). The data indicate a sharp cut in the fraction of people allowed to access funds in these plans: for instance in $1985,80 \%$ of the participants could access employer contributions "early" (prior to retirement age), but by 1997 only $52 \%$ of the participants were so able. Despite this apparent increase in access restrictiveness, there was almost a doubling in the fraction of workers allowed to take the funds in the event of "hardship". ${ }^{9}$ Access provisions for 401(k) plans are described in Table 27B, where it appears that over half of all plan participants in 1997 could obtain funds from their plans via a loan, up from 43\% in 1993. Furthermore, the modal participant could obtain a loan for any reason, not just for hardship. Therefore the pattern of employee access to DC accounts is a mixed one across plan types, with access becoming easier in 401(k) plans, but more restrictive in other DC plans over time.

Pension Payout Trends. Distribution of pension assets at retirement may take various forms. Table 28 indicates that savings/thrift plans distribute their funds as cash in the vast majority of cases, and lump sum payouts are very prevalent some $90 \%$ of participants or more have this access. Of more concern to those focused on the adequacy of retirement income is the fact that only about onequarter of participants with these plans have access to an annuity, and this percent has fallen slightly over time. Installment plans may afford some retirement income security, but here too the practice seems to be declining: only

\footnotetext{
${ }^{9}$ Exactly what constitutes a hardship according to plan sponsors is somewhat imprecise; the BLS indicates that possible reasons include purchase of repair of primary residence, illness or death in the family, education of an immediate family member, or sudden uninsured loss. More precision about the definition of hardship would be useful in future surveys, particularly since it appears that the ability to withdraw such funds without penalty is increasing.
} 
41\% in 1997 could take their funds in installments down from 59\% in 1985 . A shorter time series on payout options is available for 401(k) plans (Table 29), and here a similar pattern prevailed. In 1993 , some $34 \%$ of the participants could take their funds as a life annuity, and by 1997 this option was available to only $27 \%$. Installment options were also falling in prevalence, from $49 \%$ to $41 \%$. In general, then, workers retiring from a DC plan are less likely to have available to them the traditional annuity payout option that once was identified as the cornerstone of retirement income security. ${ }^{10}$

Investment Choices. One feature contributing to the widespread popularity of DC pension plans in the last 20 years is the fact that they typically offer employees some control over their pension investments. Table 30A illustrates trends in these choices and options for savings/thrift plans for the period 1989-1997, and Table 30B reports available information for 401(k) plans over the period 19931997.

One factor worth noting is that different provisions typically apply to employee versus employer contributions. For instance in 1997, rules governing the investment options for employee contributions were more flexible than for employer contributions. That is, in $87 \%$ of the cases employees could select their savings/thrift investment options in 1997, but this applied to only $65 \%$ of employer contributions. Eight years previously, an even smaller fraction of the employer share, $53 \%$, could be allocated by the participant. This compares to a virtually identical range of investment flexibility and investment choices for 401(k) plans in 1997 (Table 30B) in which 87\% of the employees could elect among investment choices for their own contributions and $65 \%$ of employer contributions. It is also interesting that the modal number of investment choices available for both employee and employer contributions was 3 in 1989 for

\footnotetext{
${ }^{10}$ In most cases, the retiree could probably roll DC pension assets into an Individual Retirement Account and then purchase an individual life annuity. In so doing, however, the retiree would then lose access to the group risk pooling and would be forced to pay for adverse selection costs as well as possibly higher loadings in the individual retail market (see Mitchell, Poterba, Warshawsky, and Brown forthcoming).
} 
savings/thrift plans, and 4 in 1993 for 401(k) plans; by 1997 the modal number was at least 5 choices for both plan types.

The evidence also indicates that the range of investment choices has changed over time, at least for savings/thrift plans (comparable data are unavailable for $401(\mathrm{k})$ plans). As the fraction of workers covered by savings/thrift plans increased from $18 \%$ in 1985 to $37 \%$ in to 1993 (Table 20) there were also changes in investment design features. For instance, the fraction of covered employees permitted to invest their own contributions in common stock fell from $83 \%$ in 1989 to $69 \%$ in 1997 , but this decline was partly offset by an increase in employee access to diversified stock and bond funds (from 31\% to 54\%). In 1989, half of the savings/thrift plan participants were permitted to invest their own contributions in company stock; by 1997, the fraction permitted to invest in company stock had fallen to $42 \%$. The prevalence of workers allowed to deposit their own contributions in guaranteed insurance contracts fell from $59 \%$ to $20 \%$, while those allowed to invest in bonds rose from $31 \%$ to $54 \%$ over the same period. Somewhat similar patterns appear to have applied to employer contributions in these plans, with employer stock and common stock funds declining in importance and diversified portfolios grew. Thus, while employees were offered more investment options in 1997 than they were earlier, the types of investments they could elect in their savings/thrift plans tended toward diversified stock and bond portfolios rather than the less diversified options available during the 1980 s.

Finally there is modest evidence on the periodicity with which employees in savings/thrift plans are permitted to change their investment allocations in their DC plans. The data in Table 30A cover only 1993 on but they suggest that employees are more likely to be able to exert choice over their own contributions of late. That is, in 1993 only $29 \%$ of the covered employees could change their investment options anytime, and only five years later the fraction was $47 \%$. Similarly the fraction allowed to alter the investments made with employer contributions grew from $19 \%$ to $36 \%$ in a very short time. Conversely, the number 
restricted to switching their own investments to four times a year or less fell from $48 \%$ to $24 \%$ in just five years' time (and a similar pattern applies to employer contributed assets).

\section{Conclusions}

Since the survey covers only pension plans offered by medium and large firms, the results cannot be generalized to the entire US pension environment. Nevertheless, the EBS reveals new trends in plan features, trends that are indicative of what has happened to pensions in companies that have traditionally been the most consistent providers of employer-sponsored retirement benefits in the US.

Our research has identified several key changes in the defined benefit environment. These include changes in participation and vesting rules; increased access to early retirement; declines in normal retirement ages; and the movement of pension benefit formulas toward final rather than career earnings. Benefit integration with social security also grew, but the type of integration changed substantially. Pension replacement rates appear to have fallen over time, benefit ceilings remain in place, and disability benefit provisions have become more stringent. Specific findings are summarized as follows:

- Participation rules in DB plans have become more stringent over time. In 1981, minimum age/service requirements were the norm for $59 \%$ of the participants while by 1997 some $68 \%$ had these limitations. Most plans required that a participant have either 1 year of service or attain at least age 21 with 1 year. Early in the 1980s, some firms precluded older workers from becoming plan participants if they were close to retirement age at hire, but this was outlawed in 1988.

- Vesting rules in DB plans have eased over time. Most participants now have cliff vesting ( $96 \%$ in 1997) but the modal number of years required has fallen from 10 to 5, consistent with the change in the TRA tax law. 
- Virtually no private DB pension participants are required to contribute to their own pensions out of salary.

- With regard to benefit formulas, early retirement is permitted by virtually all DB plans and has been since 1980. Normal retirement ages have declined somewhat with more have access to unreduced benefits younger than age 65 . Early retirement has long been heavily subsidized in DB plans by virtue of the fact that they use actuarially subsidized reduction factors. No substantial change in the extent of early retirement subsidies over time could be ascertained in these tabulations, though more precise information on reduction factors might reveal additional changes.

- There is a striking trend toward DB plans excluding anything other than straight-time earnings in the benefit formulas, signaling a reduction in the incentive-based portion of pensions as compared to earlier years. Fewer DB plan participants were covered by flat dollar benefit formulas by the end of the 1990s as compared to previously. Social Security integration has changed markedly in DB plans: many fewer workers have benefits offset by Social Security payments, and more workers today are covered by excess formulas that provide higher proportional benefits to those with higher earners. In plans that cap benefit payouts, they generally do so by limiting the number of years of service counted in the formula.

- DB pension payments in the private sector are vulnerable to inflation since benefits are not generally indexed to inflation. The low inflation rates of the last dozen years probably have permitted the decline in indexation.

- DB replacement rates in the past have a positive link between replacement rates and service for a given pay level, and a negative link between earnings and benefits, for a given level of service. Replacement rates in 1993 were lower than prior years, a factor that is not well explained; unfortunately the BLS did not continue the time series in subsequent years to determine if these changes in benefit provisions were permanent. 
- DB plans are increasingly permitting participants to take their benefits as a lump sum at retirement, which suggests a decline in the degree of annuitization among American workers. By 1997, almost one-fifth of participants were permitted to take a lump sum, with the overwhelming majority entitled to take their entire benefit in this form.

- Disability benefit provisions have become more stringent in DB plans over time. Fewer plans offer disability benefits, and those that do have tightened access. This may be due to increases in costs for disability benefits over time.

Turning now to a summary of findings for defined contribution plans, we are somewhat hampered by the fact that the EBS time series is not as complete over time on these plans as for the DB pensions. This is mainly because most of the series started later, but it is also because similar tabulations have not always been maintained consistently over the years. In any event, here too there are major changes in plan coverage and features over time. Most striking is an overall decline in coverage, particularly DB plan coverage among those with DC plans. Among DC participants the main plan growth was among savings/thrift pensions as well as cash/deferred salary plans; very few participants have stock or profit sharing plans. Other specific findings include the following:

- Participation and vesting requirements differ across DC plan type.

Participation barriers are lower in 401(k) plans as compared to savings/thrift and profit shaving plans, though only 1 year service is the most common requirement. Vesting data suggest that here too, rules are less stringent for 401(k) plans than virtually any other plan type (DB and DC).

- Employee contributions are the norm in DC plans, with most participants required to take employee contributions as a function of earnings - where the fraction of pay that can be contributed is usually capped at 15\%. Employers often match employee contributions with the modal match being $6 \%$ of pay, but the rate of employer match seems to be falling over time.

- Employee access to pension fund assets prior to retirement is a topic of substantial interest to policymakers. The EBS data suggest that employees are 
increasingly permitted to use loans to access their profit-sharing accounts and take hardship withdrawals, with 401(k) plans allowing the most liberal access under a wide range of circumstances (not just for hardship). Turning to retirement benefits, there has a decline in the fraction of participants that have access to a life annuity as a payout option, particularly from $401(\mathrm{k})$ pensions where only $27 \%$ have this option.

- DC plans generally offer participants some choice over investing both their own and their employer's contributions. Over time, participants have gained additional investment choices in their DC plans. Participants have also gained access to diversified stock and bond funds, with fewer permitted to invest in ownemployer stock, common stock funds and guaranteed insurance contracts.

\section{Discussion and Outlook}

The pension trends found in our tabulations of EBS pension data over time bring into focus several critical questions that will certainly drive discussion of pension design and function in the next several years. For example, small employers have moved away from DB and toward DC plans, and now our analysis confirms this trend for medium and large firms as well. In many ways, the movement toward the $\mathrm{DC}$ plan type is a logical, market-driven, response to workforce demography, new employer personnel needs, and probably most important, employee interest in investing in a healthy US stockmarket. Nevertheless, some plan features appear to contradict others, and these countervailing messages will no doubt require plan redesign in the future. For instance, the fact that many pension plans have lower hurdles for vesting and participation may help induce an aging workforce to remain on the job longer; on the other hand, employers may need to reduce the benefit subsidy for early retirement if they hope to boost DB rewards from remaining employed at older ages. Policymakers can also learn from the data on pension integration with Social Security, since those charged with solving the Social Security system's 
insolvency problems should recognize how pension costs might change in response.

These issues and others make it clear that it is important to continue the substantial data collection and tabulation effort that the EBS represents in the future. The EBS is the only employer-based nationally representative survey in the US that collates extensive data on provisions of company-provided benefits, and pensions in particular. For this reason it would be invaluable to have the identical ('core' set) tabulations carried out from the EBS for each future (and past) year of the survey. ${ }^{11}$

Some improvements could also be suggested for the EBS; inevitably, future surveys will need to adopt new questions and eliminate some old topics that are no longer relevant. It is likely that such changes would benefit from researcher and policymaker input. It would also be valuable to design tabulations that can answer parallel questions across plan types. For instance, future reports could investigate the extent to which 401(k) participants can switch investment options, a tabulation currently provided for savings/thrift plan participants. And some series seem to have been dropped despite the fact that they are of substantial interest. Our incomplete tabulations provide several such examples, but perhaps the most notable is the (incomplete) replacement rate series for DB plans.

Going further, it would be most valuable to structure future Employee Benefits Survey data so that one benefit plan could be linked with another - for instance, a health and a pension plan for a given firm could be related. This would permit analysis of potential substitution across benefit offerings. Of course researchers would also welcome the linking of information on benefit provisions and benefit costs, as well as possible labor force or other

\footnotetext{
${ }^{11}$ It would be useful to permit researchers to access the firm-level data collected over time, so as to devise additional tabulations and exploratory studies. If it were necessary for confidentiality reasons, this could probably be accomplished under restricted conditions such as those developed for restricted data users of the Health and Retirement Study (HRS); for details see http://www.umich.edu/ hrswww.
} 
consequences. ${ }^{12}$ Pension research in the $21^{\text {st }}$ century would be immeasurably benefited by such additions.

12 A more complete discussion of this approach is provided in Gustman and Mitchell (1991). 


\section{Data Appendix: The Employee Benefit Survey}

Those seeking a greater understanding of trends in pension formulas and provisions must understand how the BLS develops its Employee Benefits Survey data, on which we rely in the present report. The Employee Benefits Survey (EBS) includes information on a wide range of employee benefits provided by US employers, from health to insurance to pension plans. In the early days, these data were collected annually and only for medium and large firms. More recently, the BLS has used an alternating year format to track benefits in medium and large firms (small establishments as well as public sector employers are surveyed in other years). While the BLS does not make available to researchers the underlying firm-level reports, it does publish a set of tabulations that is more or less consistent through time. For the present purpose, we have therefore collected and examined BLS tabulations on the pension plans offered by medium and large private employers, focusing on the incidence and characteristics of pension plans described in a series of publications appearing between 1980 and $1995 .{ }^{13}$ In addition we were provided prepublication copies of the 1997 report by the BLS to round out the series. No more recent information on pension offerings by medium and large firms is available from this source today. ${ }^{14}$

Users of the data series should be aware that the BLS changed its sampling design slightly in 1998. Until that year, the Employee Benefit Survey used a sampling frame that included only firms employing at least 50,100, or 250 workers, depending on the industry in question. This in the mining, construction, retail trade, and some manufacturing and transportation sectors,

\footnotetext{
13 See BLS (various years).

14 The BLS also collects data on only three major occupation groups: professional and administrative, technical and clerical, and production and service. Not included in any surveys are data for executive management workers and part-time, seasonal, temporary, and traveling employees. Hence the figures reported below cover only these key occupational categories.
} 
the survey approached establishments employing only 250 workers or more. In accounting, auditing, and bookkeeping, the minimum firm size was 50 employees. From 1988 forward, however, the BLS elected to focus on all firms employing at least 100 workers. As a result, the survey sample size increased in 1988 from about 1,300 to about 2,100 firms by virtue of this change in scope (US DOL, 1989). In addition, the BLS extended its industrial coverage in this year. Industries analyzed prior to the change included mining; construction; manufacturing; transportation; communications; electric, gas, and sanitary services; wholesale and retail trade; finance, insurance, and real estate; and selected services. Beginning on 1988, coverage for the service sector became more extensive; in particular, health and educational services had previously been underrepresented and were thereafter included in the sample.

As a result of the sampling changes in EBS scope and coverage, we acknowledge that the pension information collected before and after 1988 is not strictly comparable. Thus in 1988 and thereafter, the BLS tabulations include more small firms and offer slightly broader industrial coverage. For the purposes of examining series overlap, the BLS did prepare some tabulations in 1988 both ways, to show how the design changes might have altered reported pension statistics. The BLS did not, however, indicate whether differences in reported tabulations due to coverage format changes are statistically significant. Where available, we provide both tabulations (for the "old" and the "new" scope) in the tables. It appears that along many of the important pension dimensions of interest here, the "old" and "new" scopes appear similar. Some differences do emerge: because the larger sample in 1988 and thereafter included smaller firms, benefit coverage as well as benefit generosity was somewhat less. Hence with the new format, in 1998 pension coverage appeared to have fallen, requirements for normal retirement appeared to have suddenly become more stringent, and plans appeared to have dropped post-retirement benefit increases among defined benefit plan participants. In the defined contribution area, more changes are evident because such plans were more prevalent among smaller firms. For this 
reason, the reader should be alert to the fact some of the differences in levels observed between 1985 and 1998 are due to the change in sampling frame. 


\section{References}

Bureau of Labor Statistics (BLS), Employee Benefits in Medium and Large

Private Establishments, US Department of Labor Bulletin, various years.

Fernandez, Phyllis. "Pre-retirement Lump Sum Distributions". In Trends in

Pensions 1992. J. Turner and D. Beller, eds. Washington, D.C.: US Dept. of Labor, PWBA, 1992.

Gustman, Alan, and Olivia S. Mitchell. "Pensions and the US Labor Market." In

Pensions and The Economy, Z. Bodie and A. Munnell, eds. Philadelphia,

PA: Univ. of Pennsylvania Press, 1992: 39-87.

Gustman, Alan L., Olivia S. Mitchell, Andrew A. Samwick, and Thomas L.

Steinmeier. "Evaluating Pension Entitlements." In Forecasting Retirement

Needs and Retirement Wealth. Eds. O.S. Mitchell, B. Hammond, and A.

Rappaport. Pension Research Council. Philadelphia, PA: University of

Pennsylvania Press, forthcoming.

Gustman, Alan, Olivia S. Mitchell, Andrew A. Samwick, and Thomas L.

Steinmeier. "Pension and Social Security Wealth in the Health and

Retirement Study". In Wealth, Work, and Health: Innovations in Survey

Measurement in the Social Sciences. Ed. Robert Willis. 1999: 150-208.

Gustman, Alan, Olivia S. Mitchell and Thomas Steinmeier. "Retirement

Measures in the Health and Retirement Survey". Journal of Human

Resources 30, Supplement (1995): S57-S83.

Gustman, Alan S., Olivia S. Mitchell and Thomas Steinmeier. "The Role of

Pensions in the Labor Market" Industrial and Labor Relations Review 47

(3) (1994): 417-438.

Ippolito, Richard A. Pensions, Economics, and Public Policy. Homewood, Il: Dow Jones-Irwin, 1986.

Levine, Phillip, Olivia Mitchell and John Phillips. "Worklife Determinants of Retirement Income Differences”. NBER WP 7243, August 1999.

Levine, Phillip, Olivia S. Mitchell, and James F. Moore. "Women on the Verge of Retirement: Predictors of Retiree Well-being”. In Forecasting Retirement 
Needs and Retirement Wealth. Eds. Olivia S. Mitchell, Brett Hammond, and Anna Rappaport. Philadelphia, PA: University of Pennsylvania Press, forthcoming.

Lumsdaine, Robin and Olivia S. Mitchell. "New Developments in the Economics of Retirement". In Handbook of Labor Economics. Orley Ashenfelter and David Card, eds. forthcoming.

Luzadis, Rebecca and Olivia S. Mitchell. "Explaining Pension Dynamics". Journal of Human Resources 26 (Fall 1991): 679-703.

McGill, Dan, John Haley, Gordon Goodfellow, and Sylvester Schieber. Fundamentals of Private Pensions, 7e. Philadelphia: University of Pennsylvania Press, 1996.

Mitchell, Olivia S. "Developments in Pensions". In Handbook of Insurance. Ed. Georges Dionne. Forthcoming. prc.wharton.upenn.edu/prc/wp98-4.PDF]. Mitchell, Olivia S. "Trends in Pension Benefit Formulas and Retirement Provisions". In Trends in Pensions 1992. J. Turner and D. Beller, eds. Washington, D.C.: US Dept. of Labor, PWBA, 1992: 177-216.

Mitchell, Olivia S. and Rebecca Luzadis. "Changes in Pension Incentives Through Time." Industrial and Labor Relations Review 42, October 1988: 100-108. Mitchell, Olivia S., James Poterba, Mark Warshawsky, Jeffrey Brown. "New Evidence on the Money's Worth of Individual Annuities". American Economic Review. forthcoming. [NBER WP 6002. April 1997.] Mitchell, Olivia S. and Sylvester Schieber, Eds. Living with Defined Contribution Pensions, Philadelphia, PA: University of Pennsylvania Press, 1998.

Mitchell, Olivia S., David McCarthy, Stanley Wisniewski, and Paul Zorn. "Developments in State and Local Pension Plans". In Public Sector Pensions. Eds. Olivia S. Mitchell and Edwin Hustead. Philadelphia, PA: University of Pennsylvania Press, forthcoming. [http://prc.wharton.upenn.edu/prc/99-4.PDF] 
Piascentini, J. and T. Cerino. EBRI Databook on Employee Benefits. Washington, D.C.: EBRI, 1990.

Rappaport, Anna M., Michael Young, Christopher Levell, and Brad Blalock. "Cash Balance Pension Plans" In Living with Defined Contribution Pensions, $_{2}$ Olivia S. Mitchell and Sylvester Schieber, Eds. Philadelphia, PA: University of Pennsylvania Press, 1998: 29-45.

Sass, Steven. The Promise of Private Pensions. Cambridge: Harvard University Press, 1997.

Turner, John and Daniel J. Beller. Trends in Pensions 1988. Washington, D.C.: US Dept. of Labor, PWBA, 1998 
Age and Length of Service Requirements for Pension Participation: Defined Benefit Pension Plans, 1981-97

\begin{tabular}{|c|c|c|c|c|c|c|c|c|c|c|c|c|c|}
\hline \multirow{3}{*}{ Type of requirements } & \multirow{2}{*}{\multicolumn{13}{|c|}{ Percent of full-time participants }} \\
\hline & & & & & & & & & & & & & \\
\hline & 1981 & 1982 & 1983 & 1984 & 1985 & 1986 & $1988 \dagger$ & 1988 & 1989 & 1991 & 1993 & 1995 & 1997 \\
\hline \multicolumn{14}{|l|}{$\begin{array}{l}\text { No minimum age } \\
\text { and/or service }\end{array}$} \\
\hline requirements & 41 & 39 & 37 & 37 & 40 & 40 & 37 & 33 & 35 & 29 & 34 & 31 & 31 \\
\hline \multicolumn{14}{|l|}{$\begin{array}{l}\text { With minimum } \\
\text { age and/or } \\
\text { service }\end{array}$} \\
\hline requirements & 59 & 61 & 63 & 63 & 59 & 59 & 63 & 66 & 66 & 71 & 66 & 69 & 68 \\
\hline Service only & 20 & 23 & 20 & 22 & 23 & 21 & 27 & 28 & 26 & 26 & 26 & 27 & 28 \\
\hline \multicolumn{14}{|l|}{1 year or } \\
\hline less & NA & NA & 18 & 20 & 21 & 17 & 23 & 24 & 22 & 26 & 26 & 25 & 27 \\
\hline Age only & 4 & 4 & 3 & 3 & 3 & 3 & 3 & 3 & 4 & 4 & 4 & 3 & 1 \\
\hline \multicolumn{14}{|l|}{ Age and } \\
\hline service & 35 & 34 & 39 & 39 & 32 & 35 & 33 & 34 & 34 & 39 & 37 & 36 & 36 \\
\hline \multicolumn{14}{|l|}{ Age 25 and 1} \\
\hline year $^{*}$ & NA & NA & 35 & 34 & NA & NA & NA & NA & NA & NA & NA & NA & NA \\
\hline \multicolumn{14}{|l|}{ Age 21 and 1} \\
\hline year* & NA & NA & NA & NA & 13 & 18 & 31 & 33 & 31 & 36 & 30 & 34 & 34 \\
\hline With maximum & & & & & & & & & & & & & \\
\hline age limitation** & 58 & 61 & 55 & 61 & 61 & 58 & 47 & 47 & NA & NA & NA & NA & NA \\
\hline
\end{tabular}

* The Employee Retirement Income Security Act (ERISA) of 1974 required that pension plans allow full-time employees age 25+ with at least 1 year of service to participate. The Retirement Equity Act of 1984 required that nearly all plans allow participation to full-time employees age $21+$ with at least 1 year of service by June 1986 . The 1986 data surveyed plans prior to the law change.

** ERISA permitted plans to impose a maximum age for participation within 5 years of the plan's normal retirement date. The Omnibus Reconciliation Act of 1986 eliminated such maximums for plan years beginning in January 1988, with slightly later dates for collectively bargained plans.

$\dagger$ In a few cases the Bureau of Labor Statistics tabulated 1988 results using a sampling frame similar to that employed in previous years. For comparability purposes these figures have been presented, where available, under columns headed "1988†," whereas tabulations from 1988 and 1989 otherwise employ the new, larger survey sampling frame.

Note: Data exclude supplemental / pension plans. Sums may not equal totals because of rounding. NA means data not available, and "---" means less than 0.5 percent.

Source: U.S. Department of Labor, Bureau of Labor Statistics, "Employee Benefits in Medium and Large Firms, 1981-1997" and unpublished data from the BLS for 1988† figures. A comparable Employee Benefits Survey (EBS) was not conducted in 1987. The EBS sampling frame changed in 1988 to include smaller firms and more industries than before, so data in 1988 and later are not precisely comparable with previous years' tabulations. 


\section{Table 2}

Vesting Schedules: Defined Benefit Pension Plans, 1980-97

\begin{tabular}{|c|c|c|c|c|c|c|c|c|c|c|c|c|c|}
\hline \multirow[b]{2}{*}{ Vesting formula } & \multicolumn{13}{|c|}{ Percent of full-time participants } \\
\hline & 1980 & 1981 & 1982 & 1983 & 1984 & 1985 & 1986 & 1988 & 1989 & 1991 & 1993 & 1995 & 1997 \\
\hline Cliff Vesting: * & 89 & 91 & 90 & 89 & 89 & 88 & 89 & 82 & 89 & 92 & 96 & 96 & 96 \\
\hline $\begin{array}{l}\text { Full vesting after: } \\
10 \text { years at any }\end{array}$ & & & & & & & & & & & & & \\
\hline $\begin{array}{l}\text { age } \\
10 \text { years after }\end{array}$ & 70 & 67 & 66 & 65 & 66 & 69 & 69 & 62 & 29 & 16 & 12 & 6 & 6 \\
\hline $\begin{array}{c}\text { given age } \\
5 \text { years at any }\end{array}$ & 19 & 21 & 22 & 22 & 19 & 17 & 18 & 15 & 9 & --- & --- & NA & --- \\
\hline age & NA & NA & NA & NA & NA & NA & NA & 45 & 44 & 69 & 79 & 87 & 85 \\
\hline Graduated & & & & & & & & & & & & & \\
\hline Vesting: ** & 11 & 13 & 12 & 13 & 14 & 13 & 13 & 17 & 11 & 8 & 4 & 3 & 3 \\
\hline $\begin{array}{l}\text { Full vesting after: } \\
<10 \text { years of }\end{array}$ & & & & & & & & & & & & & \\
\hline $\begin{array}{l}\text { service } \\
15 \text { years of }\end{array}$ & NA & NA & NA & NA & NA & NA & 6 & 9 & 9 & 5 & NA & NA & 3 \\
\hline service & 5 & 4 & 4 & 4 & 4 & 3 & 3 & 5 & 2 & NA & NA & NA & --- \\
\hline
\end{tabular}

${ }^{*}$ A cliff vesting schedule requires an employee to satisfy specific service conditions in order to become $100 \%$ vested. ERISA defined 10 years as the maximum requirement for this form of vesting. The Tax Reform Act of 1986 required single-employer plans to convert to a 5-year schedule if using cliff vesting: this provision was to be adopted by most plans during 1989 , with slightly later dates for collectively bargained plans. ${ }^{* *}$ Graduated vesting schedules give an employee rights to a gradually increasing share of accrued pension benefits, eventually reaching $100 \%$ at specified age and/or service points.

Note: Data exclude supplemental pension plans. Sums may not equal totals because of rounding. NA means data not available, and "---" means less than 0.5 percent.

Source: U.S. Department of Labor, Bureau of Labor Statistics, "Employee Benefits in Medium and Large Firms, 1980-1997." A comparable Employee Benefits Survey (EBS) was not conducted in 1987. The EBS sampling frame changed in 1988 to include smaller firms and more industries than before, so data for 1988 and later comparable with previous years' tabulations. 


\section{Table 3}

Defined Benefit Plans: Employee Contribution Requirements 1993-1997

\begin{tabular}{rrr}
\hline \multicolumn{3}{c}{ Percent of full-time participants } \\
1993 & 1995 & 1997 \\
\hline & & \\
3 & 3 & 5 \\
1 & 1 & NA \\
\hline
\end{tabular}

Note: $N A=$ not available

Source: U.S. Department of Labor, Bureau of Labor Statistics, "Employee Benefits in Medium and Large Firms, 1993-1997". 


\section{Table 4}

Minimum Age and Service Requirements for Early Retirement: Defined Benefit Pension Plans, 1980-97

Type of requirement
Plans permitting early
retirement ${ }^{*}$
Service requirements alone
30 years required
Age requirements alone
Age 55
Age and service requirements:
Age 55 and 5 years
Age 55 and 10 years
Age 55 and 15 years
Age 60 and 10 years
Age 62 and 10 years
Age plus service sum
Sum equals 80 or less
Sum equals 85 or more

$\begin{array}{lllll}980 & 1982 & 1982 & 1983 & 1984\end{array}$

$1985 \quad 1986$

1988

1989

1991

1993

1995

$\begin{array}{rrrr}98 & 98 & 97 & 97 \\ 10 & 5 & 5 & \\ 9 & 5 & 5 & 6 \\ 9 & 10 & 9 & 10 \\ 8 & 9 & 9 & 10 \\ & & & \\ 3 & 4 & 4 & 35 \\ \text { NA } & 36 & 35 & \\ \text { NA } & 11 & 10 & \\ \text { NA } & 4 & 4 & \\ \text { NA } & -- & -- & - \\ 5 & 9 & 10 & 9 \\ \text { NA } & \text { NA } & \text { NA } & 6 \\ 3 & 6 & 5 & \end{array}$

$\begin{array}{rr}97 \\ 6 \\ 6 \\ 10 \\ 10 \\ 3 \\ 35 & \\ 9 & \\ 5 & \\ -- & \\ 9 & \\ 6 & \\ 5 & \end{array}$

$\begin{array}{rr}97 & 97 \\ 5 & 4 \\ 5 & 4 \\ 10 & 9 \\ 9 & 9 \\ & \\ 4 & 3 \\ 39 & 43 \\ 7 & 8 \\ 5 & 4 \\ --- & --- \\ 10 & 10 \\ 6 & 5 \\ 5 & 4\end{array}$

$\begin{array}{rr}98 & 98 \\ 5 & 7 \\ 5 & 6 \\ 10 & 10 \\ 10 & 10 \\ & \\ 3 & 4 \\ 41 & 44 \\ 7 & 10 \\ 4 & 5 \\ -- & -- \\ 9 & 4 \\ 5 & 2 \\ 4 & 1\end{array}$

$\begin{array}{rr}97 & 98 \\ 6 & 7 \\ 5 & 6 \\ 6 & 6 \\ 6 & 5 \\ & \\ 9 & 17 \\ 43 & 32 \\ 8 & 10 \\ 4 & 4 \\ 2 & 2 \\ 4 & 6 \\ 1 & 2 \\ -- & 1\end{array}$

$\begin{array}{rrrr}98 & 95 & 96 & 95 \\ 7 & 5 & \text { NA } & 8 \\ 6 & 4 & \text { NA } & 8 \\ 6 & 2 & \text { NA } & 3 \\ 5 & 2 & \text { NA } & 3 \\ & & & \\ 17 & 20 & \text { NA } & 20 \\ 32 & 32 & \text { NA } & 30 \\ 10 & 12 & \text { NA } & 9 \\ 4 & 3 & 1 & 2 \\ 2 & 2 & -- & 1 \\ 6 & 3 & 4 & 8 \\ 2 & 2 & 3 & 6 \\ 1 & --- & -- & 1\end{array}$

Plans not permitting early retirement

2

3 3 2 2 normal age.

exclude supplemental pension plans. Sums may not equal totals because of rounding: NA means data not available, and "---" means less than 0.5 percent.

Source: U.S. Department of Labor, Bureau of Labor Statistics, "Employee Benefits in Medium and Large Firms, 1980-1997." A comparable Employee Benefits (EBS) was not conducted in 1987. The EBS sampling frame changed in 1988 to include smaller firms and more industries than before, so data for 1988 and later are not precisely comparable with previous years' tabulations. 
Minimum Age and Service Requirements for Normal Retirement:* Defined Benefit Pension Plans, 1980-97

\begin{tabular}{|c|c|c|c|c|c|c|c|c|c|c|c|c|c|c|}
\hline \multirow[b]{2}{*}{ Type of requirement } & \multirow{2}{*}{\multicolumn{14}{|c|}{ Percent of full-time participants }} \\
\hline & & & & & & & & & & & & & & \\
\hline Service requirements alone & 11 & 14 & 13 & 17 & 17 & 14 & 13 & 9 & 7 & 8 & 8 & 5 & 6 & 5 \\
\hline 30 years required & 11 & 14 & 13 & 16 & 16 & 14 & 13 & 9 & 7 & 7 & 7 & 4 & 5 & 4 \\
\hline Age requirements alone & 45 & 46 & 43 & 38 & 40 & 37 & 40 & 35 & 42 & 43 & 39 & 33 & 48 & 41 \\
\hline Age 60 & 2 & 2 & 2 & 4 & 3 & 4 & 4 & 4 & 3 & 4 & 2 & 3 & 1 & 3 \\
\hline Age 62 & 4 & 4 & 4 & 2 & 4 & 4 & 4 & 4 & 6 & 6 & 6 & 3 & 3 & 3 \\
\hline Age 65 & 39 & 39 & 36 & 31 & 33 & 29 & 32 & 27 & 33 & 33 & 30 & 26 & 36 & 29 \\
\hline Age \& service reqs. & 37 & 33 & 36 & 36 & 34 & 39 & 36 & 41 & 39 & 37 & 46 & 55 & 48 & 54 \\
\hline Age 55 and 20 years & NA & 2 & 2 & 2 & 2 & 1 & 2 & 1 & 1 & 1 & 1 & --- & --- & --- \\
\hline Age 55 and 30 years & NA & 2 & 2 & 2 & 2 & 2 & 1 & 1 & 1 & 1 & 1 & 3 & 3 & -- \\
\hline Age 60 and $1-5$ years & NA & --- & --- & --- & 2 & --- & 3 & 2 & 2 & 2 & --- & 3 & 1 & 1 \\
\hline Age 60 and 10 years & NA & 2 & 2 & 2 & 2 & 4 & 3 & 3 & 2 & 2 & 2 & 1 & 3 & 2 \\
\hline Age 60 and $15-20$ years & NA & $* * 1$ & **2 & $* * 3$ & 2 & 1 & 1 & 3 & 3 & 1 & 1 & --- & --- & 1 \\
\hline Age 60 and 30 years & NA & 2 & 2 & 4 & 3 & 3 & 3 & 2 & 1 & 3 & 2 & 4 & 2 & 2 \\
\hline Age 62 and $1-5$ years & NA & 1 & 1 & 1 & 1 & 1 & 1 & 4 & --- & 2 & 2 & 5 & 4 & 3 \\
\hline Age 62 and 10 years & NA & 8 & 9 & 6 & 7 & 11 & 7 & 13 & 11 & 10 & 7 & 7 & 9 & 11 \\
\hline Age 62 and $15-20$ years & NA & **2 & **2 & **2 & 2 & 4 & 4 & 2 & 2 & 2 & 4 & 3 & 7 & 3 \\
\hline Age 62 and 30 years & NA & 2 & 2 & 3 & 1 & 2 & 1 & 3 & 2 & 2 & --- & 1 & 2 & 1 \\
\hline Age 65 and 5 years & 2 & 1 & 1 & 1 & 1 & 1 & 2 & 1 & 1 & 2 & 10 & 15 & 9 & 15 \\
\hline Age 65 and 10 years & NA & 3 & 5 & 5 & 3 & 2 & 2 & 2 & 5 & 2 & 4 & 2 & 2 & 3 \\
\hline Age plus service sum & 6 & 7 & 8 & 9 & 9 & 10 & 11 & 15 & 12 & 12 & 6 & 8 & 9 & 8 \\
\hline Equals 80 & 1 & --- & 1 & 1 & 1 & 1 & 1 & 1 & 1 & 1 & 1 & 1 & 1 & 1 \\
\hline Equals 85 & 3 & 3 & 3 & 4 & 4 & 4 & 5 & 6 & 5 & 6 & 3 & NA & NA & NA \\
\hline Equals $90+$ & 1 & 1 & 2 & 2 & 2 & 3 & 4 & 5 & 4 & 4 & --- & 2 & 1 & -- \\
\hline
\end{tabular}

*At normal retirement a participant can retire and receive unreduced benefits immediately.

${ }^{*}$ Data available for 15 years' service only instead of $15-20$.

†n a few cases, the Bureau of Labor Statistics tabulated 1988 results using a sampling frame similar to that employed in previous years. For comparability purposes, these figures have been presented, where available, under columns headed "1988†", whereas tabulations from 1988 and 1989 otherwise employ the new, larger survey sampling frame.

Note: Data exclude supplemental pension plans. Sums may not equal totals because of rounding. NA means data not available, and "---" means less than 0.5 percent.

Source: U.S. Department of Labor, Bureau of Labor Statistics, "Employee Benefits in Medium and Large Firms, 1980-97." A comparable Employee Benefits Survey (EBS) was not conducted in 1987. The EBC sample frame changed in 1988 to include smaller firms and more industries than before, so data for 1988 and later are not precisely comparable with previous years' tabulations. 
Table 6

Benefit Formulas in Defined Benefit Pension Plans, 1980-97

\begin{tabular}{|c|c|c|c|c|c|c|c|c|c|c|c|c|c|c|}
\hline \multirow[b]{2}{*}{ Formula based on } & \multicolumn{14}{|c|}{ Percent of full-time participants } \\
\hline & 1980 & 1981 & 1982 & 1983 & 1984 & $\begin{array}{c}\text { Perc } \\
1985 \\
\end{array}$ & $\begin{array}{l}\text { of full-tin } \\
1986\end{array}$ & $\begin{array}{l}\text { participe } \\
1988 \dagger \\
\end{array}$ & 1988 & 1989 & 1991 & 1993 & 1995 & 1999 \\
\hline Dollar amount & 30 & 32 & 30 & 28 & 28 & 29 & 26 & 27 & 26 & 22 & 23 & 22 & 23 & 23 \\
\hline No alternative & 27 & 29 & 28 & 27 & 27 & 28 & 25 & 26 & 25 & 19 & 21 & 21 & 23 & 23 \\
\hline Earnings & 68 & 66 & 67 & 70 & 68 & 70 & 72 & 71 & 72 & 75 & 70 & 72 & 69 & 67 \\
\hline Terminal earnings & 53 & 50 & 52 & 54 & 54 & 57 & 57 & 54 & 55 & 64 & 56 & 61 & 58 & 56 \\
\hline No alternative & 21 & 26 & 27 & 24 & 24 & 27 & 29 & 26 & 30 & 35 & 38 & 40 & 40 & 37 \\
\hline Career earnings & 15 & 16 & 15 & 16 & 14 & 13 & 15 & 17 & 17 & 11 & 14 & 11 & 11 & 11 \\
\hline No alternative & 8 & 10 & 9 & 10 & 8 & 7 & 8 & 10 & 11 & 6 & 10 & 8 & 6 & 8 \\
\hline $\begin{array}{l}\text { Cash account or } \\
\text { money purchase }\end{array}$ & --- & --- & --- & 1 & 2 & --- & --- & 1 & 1 & 2 & 3 & 3 & 3 & 6 \\
\hline $\begin{array}{l}\text { Percent of } \\
\text { contributions }\end{array}$ & --- & 2 & 2 & 1 & 2 & 1 & --- & --- & 1 & 1 & 4 & 2 & 2 & 3 \\
\hline
\end{tabular}

*Alternative formulas are generally designed to provide a minimum benefit for employees with short service or low earnings.

†In a few cases, the Bureau of Labor Statistics tabulated 1988 results using a sampling frame similar to that employed in previous years. For comparability purposes, these figures have been presented, where available, under columns headed "1988†", whereas tabulations from 1988 and 1989 otherwise employ the new, larger survey sampling frame.

Note: Data exclude supplemental pension plans. Sums may not equal totals because of rounding. NA means data not available, and "---" means less than 0.5 percent.

Source: U.S. Department of Labor, Bureau of Labor Statistics, "Employee Benefits in Medium and Large Firms, 1980-97." A comparable Employee Benefits Survey (EBS) was not conducted in 1987. The EBC sample frame changed in 1988 to include smaller firms and more industries than before, so data for 1988 and later are not precisely comparable with previous years' tabulations. 


\section{Table 7}

\section{Definition of Earnings Used in Earnings-Based Benefit Formulas:* Defined Benefit Pension Plans, 1988-97}

Type of formula

\begin{tabular}{rrrrrr}
\hline $\begin{array}{c}\text { Total } \\
1988\end{array}$ & 1989 & 1991 & 1993 & 1995 & 1997 \\
\hline 44 & 53 & 56 & 67 & 62 & NA \\
& & & & & \\
43 & 37 & 35 & 32 & 32 & NA \\
35 & 30 & 19 & 23 & 24 & NA \\
32 & 29 & 30 & NA & NA & NA \\
32 & 28 & 20 & 19 & 18 & NA \\
\hline
\end{tabular}

*Tabulations exclude supplemental pension payments.

Note: Data exclude supplemental pension plans. Sums may not equal totals because of rounding.

Source: U.S. Department of Labor, Bureau of Labor Statistics, "Employee Benefits in Medium and Large Firms, 1988-97." Comparable Employee Benefits Survey (EBS) tabulations are not available for earlier years. 


\section{Table 8}

Career Earnings Benefit Formulas by Type: Defined Benefit Pension Plans, 1983-91

\begin{tabular}{|c|c|c|c|c|c|c|c|c|c|c|}
\hline \multirow[b]{2}{*}{ Type of formula } & \multicolumn{10}{|c|}{ Percent of full-time participants } \\
\hline & 1983 & 1984 & 1985 & 1986 & 1988 & 1989 & 1991 & 1993 & 1995 & 1997 \\
\hline Flat percent per year of service & 37 & 36 & 31 & 40 & 35 & 40 & 36 & NA & NA & NA \\
\hline Less than 1.25 percent & 7 & 5 & 6 & 5 & 3 & 8 & 6 & NA & NA & NA \\
\hline $1.25 \_1.74$ & 26 & 27 & 18 & 29 & 24 & 23 & 21 & NA & NA & NA \\
\hline $1.75-2.00$ & 1 & 3 & 1 & --- & 2 & 2 & 1 & NA & NA & NA \\
\hline 2.00 or more & 2 & 1 & 6 & 4 & 5 & 8 & 7 & NA & NA & NA \\
\hline Percent per year of service & 63 & 64 & 68 & 60 & 63 & 59 & 60 & NA & NA & NA \\
\hline By earnings & 60 & 62 & 63 & 56 & 57 & 43 & 51 & NA & NA & NA \\
\hline By service & 3 & 2 & 4 & 4 & 5 & 4 & 4 & NA & NA & NA \\
\hline Other & --- & --- & 1 & --- & 1 & 12 & 9 & NA & NA & NA \\
\hline
\end{tabular}

Note: Data exclude supplemental pension plans. Sums may not equal totals because of rounding. NA means data not availi and "---" means less than 0.5 percent.

Source: U.S. Department of Labor, Bureau of Labor Statistics, "Employee Benefits in Medium and Large Firms, 1983-97." A comparable Employee Benefits Survey (EBS) was not conducted in 1987. The EBS sampling frame changed in 1988 to include smaller firms and more industries than before, so data for 1988 and later are not precisely comparable with previous years' tabulations. 
Table 9

Terminal Earnings Benefit Formulas by Type: Defined Benefit Pension Plans, 1983-97

Type of formula

\begin{tabular}{llllllllll}
\hline \multicolumn{8}{c}{ Percent of full-time participants } \\
1983 & 1984 & 1985 & 1986 & 1988 & 1989 & 1991 & 1993 & 1995 & 1997 \\
\hline
\end{tabular}

Definition of terminal earnings:

Five years

Last 5

High 5

High consecutive 5

$\begin{array}{rrrrrrrrrr}83 & 86 & 84 & 84 & 82 & 81 & 82 & 83 & 78 & 78 \\ 5 & 2 & 5 & 4 & 4 & 3 & 6 & 3 & 3 & 1 \\ 8 & 9 & 11 & 10 & 12 & 12 & 10 & 16 & 11 & 13 \\ 70 & 75 & 70 & 69 & 67 & 65 & 67 & 65 & 64 & 65\end{array}$

Three years

Last 3

High 3

High consecutive 3

$\begin{array}{rr}14 & 11 \\ --- & 1 \\ 2 & 1 \\ 12 & 9\end{array}$

Other

Fraction of pay used in benefit formulas:

Flat percent per year of service

Loss than 1.25 percent

$1.25-1.74$

$1.75-2.00$

2.00 or more

Other percent per year of service
By earnings
By service
Other

\begin{tabular}{rrrrrrrrrr}
47 & 49 & 50 & 57 & 54 & 54 & 42 & 48 & 37 & 35 \\
8 & 5 & 6 & 7 & 6 & 12 & 9 & 9 & 12 & 11 \\
23 & 26 & 29 & 32 & 34 & 25 & 24 & 30 & 18 & 14 \\
4 & 5 & 5 & 5 & 4 & 5 & 3 & 4 & 3 & 9 \\
11 & 14 & 9 & 13 & 10 & 12 & 5 & 5 & 4 & 5 \\
& & & & & & & & & \\
53 & 51 & 50 & 43 & 46 & 46 & 57 & 51 & 62 & 65 \\
23 & 24 & 25 & 20 & 23 & 24 & 36 & 36 & 41 & 39 \\
24 & 22 & 18 & 16 & 16 & 16 & 9 & 7 & 8 & 11 \\
6 & 5 & 7 & 7 & 7 & 6 & 13 & 8 & 13 & 16 \\
\hline
\end{tabular}

Note: Data exclude supplemental pension plans. Sums may not equal totals because of rounding. NA means data not available, and "---" means less than 0.5 percent.

Source: U.S. Department of Labor, Bureau of Labor Statistics, "Employee Benefits in Medium and Large Firms, 1983-97."

A comparable Employee Benefits Survey (EBS) was not conducted in 1987. The EBS sampling frame changed in 1988 to

include smaller firms and more industries than before, so data for 1988 and later are not precisely comparable with previous years' tabulations. 


\section{Table 10}

Dollar Amount Benefit Formulas by Type: Defined Benefit Pension Plans, 1983-97

\begin{tabular}{|c|c|c|c|c|c|c|c|c|c|c|}
\hline \multirow[b]{2}{*}{ Amount per year of service } & \multicolumn{10}{|c|}{ Percent of full-time participants } \\
\hline & 1983 & 1984 & 1985 & 1986 & 1988 & 1989 & 1991 & 1993 & 1995 & 1997 \\
\hline Flat monthly amount & 71 & 75 & 66 & 59 & 73 & 81 & 95 & 97 & 94 & 97 \\
\hline$<\$ 5.00$ & 3 & --- & 3 & 4 & --- & 2 & 1 & 2 & 4 & 8 \\
\hline$\$ 5.00-9.99$ & 16 & 19 & 10 & 10 & 8 & 7 & 5 & 6 & 2 & 4 \\
\hline$\$ 10.00-14.99$ & 16 & 18 & 16 & 10 & 16 & 12 & 8 & 6 & 4 & 3 \\
\hline$\$ 15.00-19.99$ & 27 & 30 & 28 & 21 & 20 & 18 & 26 & 12 & 9 & 10 \\
\hline$\$ 20.00-24.99$ & 4 & 4 & 4 & 10 & 19 & 23 & 23 & 29 & 15 & 12 \\
\hline$\$ 25.00-29.99$ & 1 & 2 & 2 & 3 & 5 & 16 & 17 & 18 & 9 & 11 \\
\hline$\$ 30.00+$ & 3 & 2 & 2 & 2 & 5 & 3 & 15 & 25 & 51 & 50 \\
\hline Amount varies & 29 & 25 & 34 & 40 & 27 & 19 & 5 & 3 & 6 & 3 \\
\hline With service & 3 & 5 & 8 & 6 & 8 & 4 & 3 & 1 & 6 & 3 \\
\hline With earnings & 28 & 20 & 26 & 34 & 19 & 15 & 2 & 2 & --- & --- \\
\hline
\end{tabular}

Note: Data exclude supplemental pension plans. Sums may not equal totals because of rounding. NA means data not available, and "---" means less than 0.5 percent.

Source: U.S. Department of Labor, Bureau of Labor Statistics, "Employee Benefits in Medium and Large Firms, 1983-97." A comparable Employee Benefits Survey (EBS) was not conducted in 1987. The EBS sampling frame changed in 1988 to include smaller firms and more industries than before, so data for 1988 and later are not precisely comparable with previous years' tabulations. 


\section{Table 11}

\section{Integration of Benefit Payments With Social Security: Defined Benefit Pension Plans, 1980-97}

Type of formula

Without integrated formula

With integrated formula Benefit offset by SS payment*

Excess formula**

\begin{tabular}{rrrrrrrrrrrrrr}
\hline \multicolumn{10}{c}{ Percent of full-time participants } \\
1980 & 1981 & 1982 & 1983 & 1984 & 1985 & 1986 & 1988 & 1989 & 1991 & 1993 & 1995 & 1997 \\
\hline 55 & 57 & 55 & 45 & 44 & 39 & 38 & 38 & 37 & 46 & 52 & 49 & 51 \\
& & & & & & & & & & & & \\
45 & 43 & 45 & 55 & 56 & 61 & 62 & 62 & 63 & 54 & 48 & 51 & 49 \\
30 & 33 & 35 & 35 & 36 & 40 & 43 & 39 & 41 & 19 & 17 & 14 & 13 \\
16 & 10 & 10 & 20 & 20 & 27 & 24 & 26 & 24 & 36 & 31 & 37 & 36 \\
\hline
\end{tabular}

*Pension benefit calculated is reduced by a portion of primary social security payment.

${ }^{* *}$ Pension formula applies lower benefit ratio to earnings subject to social security taxes below a specified dollar threshold.

Note: Data exclude supplemental pension plans. Sums may not equal totals because of rounding.

Source: U.S. Department of Labor, Bureau of Labor Statistics, "Employee Benefits in Medium and Large Firms, 1980-97." A comparable Employee Benefits Survey (EBS) was not conducted in 1987. The EBS sampling frame changed in 1988 to include smaller firms and more industries than before, so data for 1988 and later are not precisely comparable with previous years' tabulations. 
Table 12

Reduction Factors for Early Retirement and Early Receipt of Deferred Vested Benefits: Defined Benefit Pension Plans, $1982-97$

Type of formula

\begin{tabular}{rrrr}
\hline 1982 & 1983 & 1984 & 198 \\
\hline & & & \\
& & & \\
46 & 45 & 41 & 49 \\
2 & 1 & 1 & \\
7 & 7 & 7 & 10 \\
9 & 8 & 10 & 1 \\
7 & 9 & 6 & \\
16 & 16 & 15 & 14 \\
5 & 3 & 2 &
\end{tabular}

Percent of full-time participants

(1) Early retirement reduction factor where applied:

Uniform percentage* per year Less than 3.0 percent

3.0

3.01 to 4.9

5.0 to 5.9

6.0

6.1 and over

Percent varies with:

Age

Service

3

$\begin{array}{rr}35 & 56 \\ 3 & 3\end{array}$

49
2

1986

1988

1989

1991

1993

1995

1997

(2) Deferred vested reduction factor where applied:

Uniform percentage* per year Less than 3.0 percent

3.0

3.1 to 4.9

5.0 to 5.9

6.0

6.1 and over

$\begin{array}{lll}\text { NA } & \text { NA } & \text { NA } \\ \text { NA } & \text { NA } & \text { NA } \\ \text { NA } & \text { NA } & \text { NA } \\ \text { NA } & \text { NA } & \text { NA } \\ \text { NA } & \text { NA } & \text { NA } \\ \text { NA } & \text { NA } & \text { NA } \\ \text { NA } & \text { NA } & \text { NA }\end{array}$

$\begin{array}{ll}\text { NA } & \text { NA } \\ \text { NA } & \text { NA } \\ \text { NA } & \text { NA } \\ \text { NA } & \text { NA } \\ \text { NA } & \text { NA } \\ \text { NA } & \text { NA } \\ \text { NA } & \text { NA }\end{array}$

$\begin{array}{rr}50 & 49 \\ 3 & 3 \\ 8 & 8 \\ 9 & 10 \\ 10 & 12 \\ 14 & 11 \\ 6 & 4\end{array}$

$\begin{array}{rrrr}47 & 36 & 40 & 43 \\ 3 & 2 & 4 & 3 \\ 6 & 4 & 3 & 6 \\ 10 & 10 & 7 & 6 \\ 8 & 8 & 7 & 9 \\ 15 & 11 & 14 & 17 \\ 4 & 2 & 5 & 4\end{array}$

Percent varies with:$$
\text { Age }
$$

NA

NA NA NA NA

Service

NA NA

NA

NA

NA

65

65

$\begin{array}{rrrr}65 & \text { NA } & \text { NA } & \text { NA } \\ 1 & \text { NA } & \text { NA } & \text { NA }\end{array}$

(3) Def. Vested available

prior to normal age

Reduction same

as early

*Uniform percentage early retirement factors may approximate actuarial reductions.

Note: Data exclude supplemental pension plans. Sums may not equal totals because of rounding. NA means data not available, and "---" means less than 0.5 percent.

Source: U.S. Department of Labor, Bureau of Labor Statistics, "Employee Benefits in Medium and Large Firms, 1981-97."

A comparable Employee Benefits Survey (EBS) was not conducted in 1987. The EBS sampling frame changed in 1988

to include smaller firms and more industries than before, so data for 1988 and later are not precisely comparable with previous

years' tabulations. 
Table 13

Average Pension Replacement Rates for Specified Illustrative Workers: Defined Benefit Pension Plans, 1984-97

\begin{tabular}{|c|c|c|c|c|c|c|c|c|c|}
\hline & \multirow{2}{*}{\multicolumn{9}{|c|}{ Retirement annuity as percent of final earnings }} \\
\hline \multirow{2}{*}{ Illustrative worker with } & & & & & & & & & \\
\hline & 1984 & 1985 & 1986 & 1988 & 1989 & 1991 & 1993 & 1995 & 1997 \\
\hline \multicolumn{10}{|c|}{10 years of service and final annual earnings of: } \\
\hline$\$ 15,000$ & 11.0 & 10.9 & 11.1 & 11.9 & 12.1 & 14.2 & 8.1 & NA & NA \\
\hline 20,000 & 9.9 & 9.8 & 10.0 & 10.5 & 10.9 & NA & NA & NA & NA \\
\hline 25,000 & 9.7 & 9.5 & 9.7 & 10.0 & 10.4 & 12.0 & 6.9 & NA & NA \\
\hline 30,000 & 9.7 & 9.5 & 9.7 & 9.8 & 9.9 & NA & NA & NA & NA \\
\hline 35,000 & 9.7 & 9.6 & 9.7 & 9.8 & 9.8 & 11.2 & 6.6 & NA & NA \\
\hline 45,000 & -- & --- & --- & --- & --- & 10.8 & 6.4 & NA & NA \\
\hline 55,000 & --- & --- & --- & --- & --- & 10.8 & 6.3 & NA & NA \\
\hline 65,000 & --- & --- & --- & --- & --- & 10.8 & 6.3 & NA & NA \\
\hline \multicolumn{10}{|c|}{20 years of service and final annual earnings of: } \\
\hline$\$ 15,000$ & 21.0 & 21.2 & 21.6 & 23.1 & 23.4 & 27.4 & 17.0 & NA & NA \\
\hline 20,000 & 18.8 & 19.1 & 19.5 & 20.4 & 21.1 & NA & NA & NA & NA \\
\hline 25,000 & 18.4 & 18.6 & 18.9 & 19.3 & 20.0 & 22.9 & 15.0 & NA & NA \\
\hline 30,000 & 18.5 & 18.6 & 18.9 & 19.0 & 19.8 & NA & NA & NA & NA \\
\hline 35,000 & 18.6 & 18.7 & 19.1 & 19.1 & 19.9 & 21.4 & 14.1 & NA & NA \\
\hline 45,000 & --- & --- & --- & --- & --- & 20.9 & 13.5 & NA & NA \\
\hline 55,000 & --- & --- & --- & --- & --- & 20.8 & 13.3 & NA & NA \\
\hline 65,000 & --- & --- & --- & --- & --- & 20.1 & 13.3 & NA & NA \\
\hline \multicolumn{10}{|c|}{30 years of service and final annual earnings of: } \\
\hline$\$ 15,000$ & 30.8 & 31.4 & 31.5 & 33.5 & 34.6 & 39.3 & 27.0 & NA & NA \\
\hline 20,000 & 27.4 & 28.3 & 28.5 & 29.6 & 31.3 & NA & NA & NA & NA \\
\hline 25,000 & 26.6 & 27.6 & 27.6 & 28.0 & 29.7 & 32.5 & 23.6 & NA & NA \\
\hline 30,000 & 26.5 & 27.3 & 27.4 & 27.3 & 29.4 & NA & NA & NA & NA \\
\hline 35,000 & 26.5 & 27.3 & 27.4 & 27.3 & 29.5 & 30.8 & 22.2 & NA & NA \\
\hline 45,000 & --- & --- & --- & --- & --- & 30.2 & 21.5 & NA & NA \\
\hline 55,000 & --- & --- & --- & --- & --- & 29.0 & 21.0 & NA & NA \\
\hline 65,000 & --- & --- & --- & --- & --- & 29.1 & 21.0 & NA & NA \\
\hline
\end{tabular}

*The maximum private pension was calculated using the earnings and service shown, not reduced for early retirement or joint-and-survivor annuities. Replacment rates refer to the ratio of the retirement pension to the final year's earnings.

Note: Data exclude supplemental pension plans. Sums may not equal totals because of rounding. NA means data not available, and "---" means less than 0.5 percent.

Source: U.S. Department of Labor, Bureau of Labor Statistics, "Employee Benefits in Medium and Large Firms, 1984-97."

A comparable Employee Benefits Survey (EBS) was not conducted in 1987. The EBS sampling frame changed in 1988

to include smaller firms and more industries than before, so data for 1988 and later are not precisely comparable with previous years' tabulations. 
Table 14

Prevalence of Ad hoc Postretirement Benefit Annuity Increases:*

Defined Benefit Pension Plans, 1983-97

Benefit increases

\begin{tabular}{llllllllll}
\hline \multicolumn{1}{c}{ Percent of full-time participants } \\
1983 & 1984 & 1985 & 1986 & 1988 & 1989 & 1991 & 1993 & 1995 & 1997 \\
\hline
\end{tabular}

At least one postretirement increase in last

5 years

51

$47 \quad 41 \quad 35$

27

24

$---10$

$10 \quad \mathrm{NA}$

Automatic COLA

Discretionary in last 5 years

\begin{tabular}{cccccccccc}
--- & --- & --- & --- & --- & --- & -- & 4 & 3 & -- \\
--- & --- & --- & --- & --- & --- & --- & 6 & 4 & --- \\
\hline
\end{tabular}

*Unscheduled increases in pension payments for already-retired employees.

${ }^{* *}$ Figures exclude one-time lump-sum payments.

Note: Data exclude supplemental pension plans. Sums may not equal totals because of rounding.

Source: U.S. Department of Labor, Bureau of Labor Statistics, "Employee Benefits in Medium and Large Firms, 1983-97." A comparable Employee Benefits Survey (EBS) was not conducted in 1987. The EBS sampling frame changed in 1988 to include smaller firms and more industries than before, so data for 1988 and later are not precisely comparable with previous years' tabulations. 


\section{Table 15}

Maximum Benefit Provisions: Defined Benefit Pension Plans, 1984-97

\begin{tabular}{|c|c|c|c|c|c|c|c|c|c|}
\hline \multirow[b]{2}{*}{ Type of formula } & \multicolumn{9}{|c|}{ Percent of full-time participants } \\
\hline & 1984 & 1985 & 1986 & 1988 & 1989 & 1991 & 1993 & 1995 & 1997 \\
\hline Not subject to maximum & 58 & 60 & 59 & 60 & 59 & 61 & 63 & 65 & 67 \\
\hline Subject to maximum* & 42 & 40 & 41 & 40 & 41 & 39 & 37 & 35 & 33 \\
\hline Limit on service years & 34 & 34 & 36 & 37 & 37 & 37 & 37 & 33 & 31 \\
\hline Less than 20 & 2 & 2 & 2 & 1 & 1 & 1 & 5 & 5 & -- \\
\hline $20-29$ & 5 & 3 & 6 & 6 & 5 & 5 & 5 & 5 & 6 \\
\hline $30-39$ & 32 & 24 & 22 & 23 & 24 & 25 & 25 & 29 & 19 \\
\hline 40 or more & 4 & 5 & 7 & 9 & 9 & 8 & 7 & 5 & 6 \\
\hline Other limit & 11 & 8 & 7 & 6 & 6 & 4 & 1 & 1 & 2 \\
\hline
\end{tabular}

*Sums of individual items do not equal totals because more than one maximum may apply.

Note: Data exclude supplemental pension plans. Sums may not equal totals because of rounding.

Source: U.S. Department of Labor, Bureau of Labor Statistics, "Employee Benefits in Medium and Large Firms, 1984-97." A comparable Employee Benefits Survey (EBS) was not conducted in 1987. The EBS sampling frame changed in 1988 to include smaller firms and more industries than before, so data for 1988 and later are not precisely comparable with previous years' tabulations. 


\section{Table 16}

\section{Disability Retirement Provisions: Defined Benefit Pension Plans, 1980-97}

\section{Plan characteristics}

Disability retirement available

Minimum requirements for disability retirement where available:

No age or service

Service only

Age only

Qualifies for LTD*

Benefit provisions for disability retirement where available: Immediate

Unreduced normal

Other

Deferred

Service credit to retirement

Other

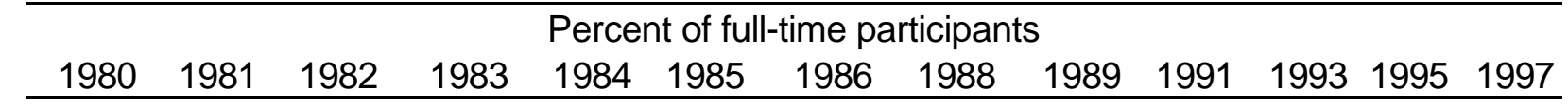

$\begin{array}{lllllllllllll}87 & 88 & 89 & 91 & 90 & 85 & 89 & 92 & 81 & 79 & 69 & 73 & 75\end{array}$

$\begin{array}{rrrrrrrrrrrrr}16 & 15 & 16 & 14 & 17 & 16 & 13 & 13 & 12 & 20 & 11 & 11 & \text { NA } \\ 61 & 57 & 56 & 57 & 52 & 54 & 50 & 57 & 56 & 54 & 36 & 28 & \text { NA } \\ 1 & 1 & --- & --- & --- & --- & --- & 1 & --- & --- & 1 & --- & \text { NA } \\ 11 & 18 & 20 & 21 & 22 & 20 & 25 & 31 & 31 & 18 & 16 & 17 & \text { NA }\end{array}$

\begin{tabular}{rrrrrrrrrrrrr}
70 & 67 & 66 & 66 & 62 & 60 & 55 & 52 & 57 & 63 & 41 & 45 & 46 \\
55 & 51 & 51 & 50 & 48 & 47 & 41 & 39 & 42 & 46 & 32 & 29 & 30 \\
15 & 16 & 15 & 16 & 14 & 13 & 14 & 13 & 15 & 17 & 9 & 16 & 17 \\
30 & 33 & 34 & 34 & 38 & 40 & 45 & 48 & 43 & 37 & 23 & 28 & 28 \\
24 & 27 & 30 & 29 & 31 & 32 & 37 & 39 & 37 & 28 & 24 & 24 & 24 \\
6 & 6 & 4 & 5 & 7 & 8 & 8 & 9 & 6 & 9 & 4 & 4 & 4 \\
\hline
\end{tabular}

${ }^{*}$ Long term disability insurance.

Note: Data exclude supplemental pension plans. Sums may not equal totals because of rounding. NA means data not available, and "---" means less than 0.5 percent.

Source: U.S. Department of Labor, Bureau of Labor Statistics, "Employee Benefits in Medium and Large Firms, 1980-97." A comparable Employee Benefits Survey (EBS) was not conducted in 1987. The EBS sampling frame changed in 1988 to include smaller firms and more industries than before, so data for 1988 and later are not precisely comparable with previous years' tabulations. 
Table 17

Defined Benefit Plans: Lump Sum Available at Retirement, 1991-97

\begin{tabular}{crrrr} 
& \multicolumn{4}{c}{ Percent of full time participants } \\
& 1991 & 1993 & 1995 & 1997 \\
\cline { 2 - 5 } & & & & \\
\% with Lump Sum & 14 & 10 & 15 & 23 \\
Full Amount & 9 & 9 & 15 & 22 \\
Amount Limited & 5 & 3 & 5 & 1 \\
\cline { 2 - 5 }
\end{tabular}

Note: Sums may not add up due to rounding.

Source: U.S. Department of Labor, Bureau of Labor Statistics, "Employee Benefits in Medium and Large Firms, 1991-1997." 


\section{Table 18}

Participation in Retirement and Capital Accumulation Plans, 1985-97

\begin{tabular}{|c|c|c|c|c|c|c|c|c|c|}
\hline \multirow[b]{2}{*}{ Plan participation } & \multicolumn{9}{|c|}{ Percent of full-time employees } \\
\hline & 1985 & 1986 & $1988 \dagger$ & 1988 & 1989 & 1991 & 1993 & 1995 & 1997 \\
\hline Not covered by a plan & 8 & 9 & 12 & 18 & 17 & 21 & NA & NA & NA \\
\hline Covered by a plan & 92 & 91 & 88 & 82 & 83 & 79 & NA & NA & NA \\
\hline Retirement only* & 71 & 67 & 69 & 68 & 69 & 69 & NA & NA & NA \\
\hline Capital accumulation only** & 1 & 1 & 2 & 2 & 1 & 1 & NA & NA & NA \\
\hline Both & 20 & 22 & 17 & 12 & 12 & 9 & NA & NA & NA \\
\hline
\end{tabular}

*Includes defined benefit and defined contribution plans such as money purchase pensions, profit sharing, and savings and thrift plans when employer contributions must remain in the participant's account until retirement, death, disability, separation from service, age $591 / 2$, or hardship.

**Includes plan in which employer contributions may be withdrawn from participant's account prior to retirement, death, disability, separation from service, age 59 1/2, or hardship. †ln a few cases the Bureau of Labor Statistics tabulated 1988 results using a sampling frame similar to that employed in previous years. For comparability purposes these figures have been presented, where available, under columns headed "1988†," whereas tabulations from 1988 and 1989 otherwise employ the new, larger survey sampling frame.

Note: Data exclude supplemental / pension plans. Sums may not equal totals because of rounding.

Source: U.S. Department of Labor, Bureau of Labor Statistics, "Employee Benefits in Medium and Large Firms, 1980-1997." A comparable Employee Benefits Survey (EBS) was not conducted in 1987. The EBS sampling frame changed in 1988 to include smaller firms and more industries than before, so data for 1988 and later are not precisely comparable with previous years' tabulations. 
Table 19

Combinations of Retirement and Capital Accumulation Plans, 1985-97

\begin{tabular}{|c|c|c|c|c|c|c|c|c|}
\hline \multirow[b]{2}{*}{ Combinations covering participants } & \multicolumn{8}{|c|}{ Percent of full-time participants } \\
\hline & 1985 & 1986 & 1988 & 1989 & 1991 & 1993 & 1995 & 1997 \\
\hline Defined benefit plan with: & 89 & 85 & 76 & 76 & 59 & 56 & 52 & 50 \\
\hline No other plan & 45 & 35 & 45 & 42 & 35 & 61 & NA & NA \\
\hline Profit sharing* & 5 & 13 & 9 & 7 & 5 & 3 & NA & NA \\
\hline Savings/thrift & 15 & 15 & 21 & 24 & 15 & 17 & NA & NA \\
\hline Stock plan & 23 & 22 & 1 & 2 & 1 & NA & NA & NA \\
\hline Money purchase & -- & -- & 1 & 1 & 1 & 2 & NA & NA \\
\hline Profit sharing plan with: & 9 & 11 & 12 & 10 & 16 & 13 & 13 & 13 \\
\hline No other plan & 7 & 8 & 10 & 8 & 8 & 6 & NA & NA \\
\hline Savings/thrift & 1 & 1 & 1 & 1 & 1 & 2 & NA & -- \\
\hline Stock plan & 1 & 1 & 1 & 1 & --- & NA & NA & NA \\
\hline Money purchase plan with: & --- & --- & 5 & 5 & 7 & 8 & 7 & 8 \\
\hline No other plan & --- & --- & 5 & 4 & 5 & NA & NA & NA \\
\hline Savings/thrift & --- & --- & 1 & 1 & 1 & NA & NA & NA \\
\hline Savings/thrift plan with: & 1 & 3 & 5 & 8 & 29 & 29 & 41 & 39 \\
\hline No other plan & 1 & 2 & 5 & 8 & 15 & 5 & NA & NA \\
\hline Stock plan with: & --- & 1 & 1 & 1 & 2 & --- & 2 & 1 \\
\hline No other plan & --- & 1 & 1 & 1 & NA & NA & NA & NA \\
\hline
\end{tabular}

*Includes profit sharing and saving/stock combination plans; excludes pure cash profit sharing plans.

Note: Data exclude supplemental pension plans. Sums may not equal totals because of rounding. NA means data not available, and "---" means less than 0.5 percent.

Source: U.S. Department of Labor, Bureau of Labor Statistics, "Employee Benefits in Medium and Large Firms, 1985-97." A comparable Employee Benefits Survey (EBS) was not conducted in 1987. The EBS sampling frame changed in 1988 to include smaller firms and more industries than before, so data for 1988 and later are not precisely comparable with previous years' tabulations. 
Table 20

Participation In Cash or Deferred Plans Including Salary Reduction Plans, 1985-97

Type of plan

Cash or deferred plan*

Salary reduction plan

Salary and thrift

Profit sharing

Money purchase

Other

\begin{tabular}{lllllllll}
\hline \multicolumn{8}{c}{ Percent of full-time employees } \\
1985 & 1986 & $1988+$ & 1988 & 1989 & 1991 & 1993 & 1995 & 1997 \\
\hline
\end{tabular}

\begin{tabular}{rrrrrrrrr}
\hline 26 & 33 & 42 & 36 & 41 & 44 & 36 & 45 & NA \\
26 & 31 & 40 & 34 & 38 & 40 & 35 & 44 & NA \\
18 & 21 & 27 & 22 & 28 & 28 & 29 & 37 & NA \\
4 & 6 & 9 & 7 & 4 & 4 & 4 & 5 & NA \\
1 & 1 & --- & --- & 1 & 1 & NA & NA & NA \\
3 & 3 & 5 & 6 & 5 & 4 & 3 & 2 & NA \\
\hline
\end{tabular}

${ }^{*}$ Cash or deferred plans are included only if they allow income to be deferred; data include employee contributions to various retirement plans but exclude cases where employee contributions may be required to a defined benefit pension plan.

†In a few cases the Bureau of Labor Statistics tabulated 1988 results using a sampling frame similar to that employed in previous years. For comparability purposes these figures have been presented, where available, under columns headed "1988†," whereas tabulations from 1988 and 1989 otherwise employ the new, larger survey sampling frame.

Note: Data exclude supplemental / pension plans. Sums may not equal totals because of rounding. NA means data not available, and "---" means less than 0.5 percent.

Source: U.S. Department of Labor, Bureau of Labor Statistics, "Employee Benefits in Medium and Large Firms, 1985-1997" and unpublished data from the BLS for 1988? Figures. A comparable Employee Benefits Survey (EBS) was not conducted in 1987. The EBS sampling frame changed in 1988 to include smaller firms and more industries than before, so data for 1988 and later are not precisely comparable with previous years' tabulations. 


\section{Table 21}

Participation in Defined Contribution Plans, 1985-97

Type of plan

$$
\text { Percent of full-time employees }
$$

Savings and thrift

Profit sharing

Stock ownership

Stock bonus

Money purchase

\begin{tabular}{rrrrrrrrr}
1985 & 1986 & $1988 \dagger$ & 1988 & 1989 & 1991 & 1993 & 1995 & 1997 \\
\hline 27 & 28 & 32 & 25 & 30 & 29 & 29 & 41 & 39 \\
18 & 22 & 21 & 18 & 16 & 16 & 13 & 13 & 13 \\
24 & 30 & 2 & 2 & 3 & 3 & 3 & 5 & 4 \\
1 & --- & --- & --- & --- & --- & --- & 2 & NA \\
4 & 2 & 3 & 6 & 5 & 7 & 8 & 7 & 8 \\
\hline
\end{tabular}

†In a few cases the Bureau of Labor Statistics tabulated 1988 results using a sampling frame similar to that employed in previous years. For comparability purposes these figures have been presented, where available, under columns headed "1988†," whereas tabulations from 1988 and 1989 otherwise employ the new, larger survey sampling frame.

Note: Data exclude supplemental / pension plans. Sums may not equal totals because of rounding. NA means data not available, and "---" means less than 0.5 percent.

Source: U.S. Department of Labor, Bureau of Labor Statistics, "Employee Benefits in Medium and Large Firms, 1985-1997" and unpublished data from the BLS for 1988† figures. A comparable Employee Benefits Survey (EBS) was not conducted in 1987. The EBS sampling frame changed in 1988 to include smaller firms and more industries than before, so data for 1988 and later are not precisely comparable with previous years' tabulations. 
Table 22

Age and Length of Service Requirements for Participation, Savings and Thrift, Deferred Sharing Plans and 401(k) Plans, 1985-97

\begin{tabular}{|c|c|c|c|c|c|c|c|c|}
\hline \multirow{3}{*}{$\begin{array}{l}\text { Type of requirement } \\
\text { Savings and Thrift Plans }\end{array}$} & \multirow{2}{*}{\multicolumn{8}{|c|}{ Percent of full-time participants }} \\
\hline & & & & & & & & \\
\hline & 1985 & 1986 & 1988 & 1989 & 1991 & 1993 & 1995 & 1997 \\
\hline No minimum age $\&$ service requirements & 14 & 10 & 14 & 15 & 18 & 17 & NA & $\overline{N A}$ \\
\hline \multicolumn{9}{|l|}{ With minimum age and/or } \\
\hline service requirements* & 86 & 90 & 86 & 85 & 82 & 81 & NA & NA \\
\hline Service only & 70 & 73 & 64 & 62 & 57 & 55 & 68 & 76 \\
\hline$<1$ year & 16 & 15 & 11 & 12 & 13 & 14 & 11 & 22 \\
\hline 1 year & 48 & 50 & 43 & 45 & 39 & 38 & 55 & 52 \\
\hline $2+$ years & 6 & 7 & 10 & 5 & 4 & 2 & 2 & 2 \\
\hline \multicolumn{9}{|l|}{ Age requirements } \\
\hline Age 20 or less & 4 & 6 & 6 & 5 & 4 & 8 & NA & NA \\
\hline and 1 year service & 2 & 2 & 2 & 1 & 2 & 5 & NA & NA \\
\hline Age 21 & 11 & 10 & 16 & 19 & 21 & 18 & NA & NA \\
\hline and 1 year service & 6 & 8 & 13 & 15 & 18 & 14 & NA & NA \\
\hline Deferred Profit Sharing Plans & 1985 & 1986 & 1988 & 1989 & 1991 & 1993 & 1995 & 1997 \\
\hline No minimum age $\&$ service requirements & NA & 14 & 9 & 6 & 5 & 16 & 24 & $\overline{\mathrm{NA}}$ \\
\hline \multicolumn{9}{|l|}{ With minimum age and/or } \\
\hline service requirements* & NA & 86 & 91 & 94 & 95 & 82 & 76 & NA \\
\hline Service only & NA & 69 & 66 & 65 & 60 & 55 & 76 & 68 \\
\hline$<1$ year & NA & 11 & 15 & 4 & 6 & 14 & 9 & 13 \\
\hline 1 year & NA & 49 & 44 & 54 & 52 & 37 & 59 & 54 \\
\hline $2+$ years & NA & 9 & 6 & 6 & 2 & 3 & 8 & 1 \\
\hline \multicolumn{9}{|l|}{ Age requirements } \\
\hline Age 20 or less & NA & 3 & 4 & 4 & 6 & 11 & NA & NA \\
\hline and 1 year service & NA & 2 & 1 & 1 & 5 & 6 & NA & NA \\
\hline Age 21 & NA & 12 & 21 & 25 & 29 & 16 & NA & NA \\
\hline and 1 year service & NA & 7 & 19 & 23 & -- & 12 & NA & NA \\
\hline 401(k) Plans & 1993 & 1995 & 1997 & & & & & \\
\hline No minimum age $\&$ service requirements & 17 & 27 & 27 & & & & & \\
\hline With minimum age/seniority & 81 & NA & NA & & & & & \\
\hline Service only & 53 & 67 & NA & & & & & \\
\hline$<1$ year & 14 & 11 & 13 & & & & & \\
\hline 1 year & 35 & 52 & 54 & & & & & \\
\hline $2+$ years & 3 & 4 & 1 & & & & & \\
\hline
\end{tabular}

*The Retirement Equity Act of 1984 required that nearly all plans allow participation to fulltime empployees who have reached age 21 and have completed 1 year of service. Plans may impose a service requirement of up to 3 years if vesting is then immediate on participation. The compliance date for most plans was June 1986, but collectively bargained plus had slightly longer to comply.

Note: Data exclude supplemental / pension plans. Sums may not equal totals because of rounding. NA means data not available.

Source: U.S. Department of Labor, Bureau of Labor Statistics, "Employee Benefits in Medium and Large Firms, 1985-1997" and unpublished data from the BLS for 1988† figures. A

comparable Employee Benefits Survey (EBS) was not conducted in 1987. The EBS sampling frame changed in 1988 to include smaller firms and more industries than before, so data for 1988 and later are not precisely comparable with previous years' tabulations. 


\section{Table 23}

Vesting Schedules: Savings and Thrift, Deferred Profit Sharing, and 401(k) Plans, 1985-97

\begin{tabular}{|c|c|c|c|c|c|c|c|c|}
\hline \multirow{3}{*}{ Savings and Thrift Plans } & \multirow{2}{*}{\multicolumn{8}{|c|}{ Percent of full-time participants }} \\
\hline & & & & & & & & \\
\hline & 1985 & 1986 & 1988 & 1989 & 1991 & 1993 & 1995 & 1997 \\
\hline \multicolumn{9}{|l|}{ Type of formula } \\
\hline Immediate full vesting & 25 & 26 & 27 & 30 & 31 & 34 & 33 & 29 \\
\hline \multicolumn{9}{|l|}{ Cliff vesting ${ }^{*}$ with full } \\
\hline vesting after & 12 & 20 & 20 & 24 & 31 & 29 & 25 & 30 \\
\hline $1-2$ years & 3 & 5 & 3 & 2 & 2 & 2 & 1 & 3 \\
\hline $3-4$ & 2 & 7 & 7 & 11 & 9 & 9 & 5 & 6 \\
\hline $5+$ & 7 & 8 & 10 & 12 & 19 & 18 & 18 & 21 \\
\hline \multicolumn{9}{|l|}{ Graduated vesting ${ }^{* *}$ with } \\
\hline full vesting after & 28 & 25 & 32 & 30 & 35 & 33 & 24 & 33 \\
\hline$<4$ years & 4 & 2 & 4 & 4 & 3 & 5 & 3 & 10 \\
\hline 5 & 16 & 15 & 21 & 19 & 21 & 18 & 12 & 15 \\
\hline $6-9$ & 4 & 4 & 3 & 5 & 10 & 10 & 8 & 9 \\
\hline $10+$ & 4 & 4 & 4 & 2 & --- & --- & --- & --- \\
\hline Other & 35 & 29 & 21 & 16 & --- & --- & --- & --- \\
\hline Deferred Profit Sharing Plan & 1985 & 1986 & 1988 & 1989 & 1991 & 1993 & 1995 & 1997 \\
\hline Immediate full vesting & NA & 29 & 22 & 37 & 40 & 18 & 37 & 29 \\
\hline \multicolumn{9}{|l|}{ Cliff vesting ${ }^{*}$ with full } \\
\hline vesting after & NA & 2 & 2 & 12 & 18 & 21 & 22 & 30 \\
\hline $1-2$ years & NA & 2 & --- & --- & --- & --- & 2 & 3 \\
\hline $3-4$ & NA & 1 & --- & 4 & 1 & 6 & 2 & 6 \\
\hline $5+$ & NA & 1 & 2 & 8 & 16 & 15 & 17 & 21 \\
\hline \multicolumn{9}{|l|}{ Graduated vesting ${ }^{\star *}$ with } \\
\hline full vesting after & NA & 66 & 73 & 50 & 41 & 55 & 34 & 33 \\
\hline$<4$ years & NA & --- & 1 & 2 & 2 & 2 & 1 & 10 \\
\hline 5 & NA & 3 & 7 & 6 & 4 & 16 & 4 & 15 \\
\hline $6-9$ & NA & 14 & 29 & 28 & 37 & 37 & 28 & 9 \\
\hline $10+$ & NA & 49 & 35 & 15 & --- & 1 & 1 & --- \\
\hline Other & NA & 4 & 2 & 1 & --- & --- & --- & --- \\
\hline
\end{tabular}




\section{Table 23 (continued)}

\section{1(k) Plans}

Immediate full vesting

Cliff vesting* with full vesting after

$$
\text { 1-2 years }
$$

3-4

$5+$

Graduated vesting ${ }^{* *}$ with

full vesting after

$$
<4 \text { years }
$$

5

6-9

$10+$

Other
1993

1995

1997

\begin{tabular}{rrr}
\hline 1993 & 1995 & 1997 \\
\hline 34 & 39 & 34 \\
26 & 24 & 27 \\
2 & 1 & 3 \\
8 & 5 & 5 \\
16 & 18 & 19 \\
& & \\
37 & 27 & 32 \\
4 & 3 & 11 \\
18 & 13 & 13 \\
14 & 10 & 9 \\
--- & --- & -- \\
--- & --- & -- \\
\hline
\end{tabular}

${ }^{*}$ A cliff vesting schedule requires an employee to satisfy specific service conditions in order to become $100 \%$ vested. ERISA defined 10 years as the maximum requirement for this form of vesting. The Tax Reform Act of 1986 required single-employer plans to convert to a 5-year schedule is using cliff vesting; this provision was to be adopted by most plans during 1989 , with slightly later dates for collectively bargained plans.

${ }^{* *}$ Graduated vesting schedules give an employee rights to a gradually increasing share of accrued pension benefits, eventually reaching $100 \%$ at specified age and/or service points. Note: Data exclude supplemental / pension plans. Sums may not equal totals because of rounding. NA means data not available, and "---" means less than 0.5 percent.

Source: U.S. Department of Labor, Bureau of Labor Statistics, "Employee Benefits in Medium and Large Firms, 1985-1997" and unpublished data from the BLS for $1988+$ figures. A

comparable Employee Benefits Survey (EBS) was not conducted in 1987. The EBS sampling frame changed in 1988 to include smaller firms and more industries than before, so data for 1988 and later are not precisely comparable with previous years' tabulations. 


\section{Employee Contributions in Savings and Thrift and 401(k) Plans, 1985-97}

\section{Savings and Thrift Plans}

Type of formula

Basis of maximum contribution, if allowed/required: Specified dollar amount

Fraction of earnings

$<5 \%$

$6-9$

$11-14$

15

16

17-19

$20+$

Other

Tax status of contribution, if allowed/required:

Pretax contribution

Not allowed

Allowed

\section{1(k) Plans}

Basis of maximum contribution, if allowed/required: Specified dollar amount

Fraction of earnings

$<5 \%$

6-9

10

$11-14$

15

16

17-19

$20+$

Other

Tax status of contribution, if allowed/required:

Pretax contribution

Not allowed

Allowed

\begin{tabular}{rrr}
\hline 1985 & 1986 & 1988 \\
& & \\
2 & 2 & \\
97 & 98 & 95 \\
--- & 1 & \\
5 & 10 & 8 \\
17 & 13 & 13 \\
21 & 20 & 19 \\
8 & 9 & 14 \\
32 & 29 & 24 \\
8 & 8 & 9 \\
6 & 7 & 6 \\
1 & --- & 3
\end{tabular}

Percent of participants

$1989 \quad 1991$

1993

1995

1997

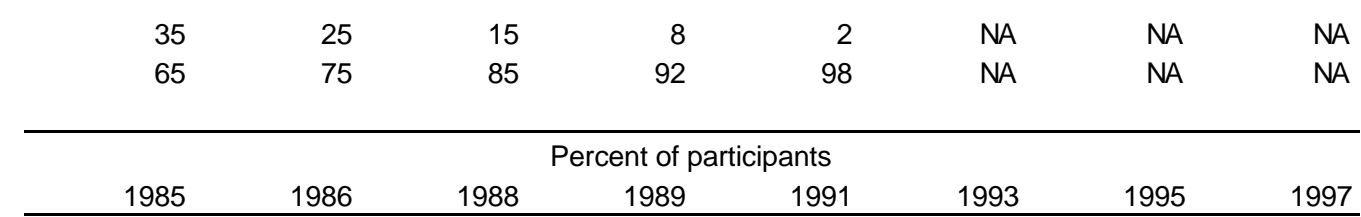

\begin{tabular}{|c|c|c|c|c|c|c|c|}
\hline NA & NA & NA & NA & $N A$ & 2 & 1 & 1 \\
\hline NA & NA & NA & NA & $N A$ & 91 & 83 & 87 \\
\hline NA & NA & NA & $\mathrm{NA}$ & $N A$ & 5 & 4 & 4 \\
\hline NA & $\mathrm{NA}$ & NA & NA & NA & 8 & 10 & 5 \\
\hline NA & NA & NA & NA & NA & 19 & 12 & 11 \\
\hline NA & NA & NA & NA & $N A$ & 15 & 13 & 11 \\
\hline NA & NA & NA & NA & NA & 19 & 20 & 31 \\
\hline NA & NA & NA & NA & $N A$ & 16 & 12 & 11 \\
\hline NA & NA & NA & NA & NA & 4 & 7 & 7 \\
\hline NA & NA & NA & NA & NA & 2 & 5 & 3 \\
\hline NA & NA & NA & NA & $N A$ & 7 & 16 & 12 \\
\hline NA & NA & NA & NA & NA & NA & NA & NA \\
\hline NA & NA & NA & NA & NA & NA & NA & NA \\
\hline
\end{tabular}

Note: Data exclude supplemental / pension plans. Sums may not equal totals because of rounding. NA means data not available, and "---" means less than 0.5 percent.

Source: U.S. Department of Labor, Bureau of Labor Statistics, "Employee Benefits in Medium and Large Firms, 1985-1997" and unpublished data from the BLS for 1988? Figures. A comparable Employee Benefits Survey (EBS) was not conducted in 1987. The EBS sampling frame

changed in 1988 to include smaller firms and more industries than before, so data for 1988 and later are not precisely comparable with previous years' tabulations. 


\section{Table 25}

\section{Employer Contributions in Savings and Thrift Plans, 1985-97}

\begin{tabular}{|c|c|c|c|c|c|c|c|c|}
\hline \multirow[b]{2}{*}{ Employer matching ${ }^{*}$ contributions } & \multicolumn{8}{|c|}{ Percent of full-time participants } \\
\hline & 1985 & 1986 & 1988 & 1989 & 1991 & 1993 & 1995 & 1997 \\
\hline Specified dollar amount & 9 & 7 & 5 & 4 & 1 & NA & NA & NA \\
\hline Fraction of salary up to: & & & & & & & & \\
\hline$<5 \%$ & 12 & 28 & 35 & 36 & 39 & 40 & NA & NA \\
\hline $6 \%$ & 52 & 54 & 47 & 47 & 43 & 46 & NA & NA \\
\hline$>7 \%$ & 14 & 11 & 11 & 12 & 14 & 15 & NA & NA \\
\hline
\end{tabular}

*Employees may contribute a percentage of salary up to a maximum; ceilings on employer matching contributions are generally lower.

Note: Data exclude supplemental / pension plans. Sums may not equal totals because of rounding. NA means data not available, and "---" means less than 0.5 percent.

Source: U.S. Department of Labor, Bureau of Labor Statistics, "Employee Benefits in Medium and Large Firms, 1985-1997" and unpublished data from the BLS for 1988† figures. A comparable Employee Benefits Survey (EBS) was not conducted in 1987. The EBS sampling frame changed in 1988 to include smaller firms and more industries than before, so data for 1988 and later are not precisely comparable with previous years' tabulations. 


\section{Table 26}

\section{Provisions of Deferred Profit Sharing Plans, 1986-97}

Type of formula

Employer contributions:

(1) Based on stated formula

Fixed \% of profits

Variable $\%$ of profits

Other formulas

(2) No formula

Allocation of profits to employees:

Equally to all

Based on earnings

Based on earnings and service

Other

Loans from employee's accounts:

Permitted

Not permitted

\begin{tabular}{rrrrrrr}
\hline \multicolumn{7}{c}{ Percent of full-time participants } \\
1986 & 1988 & 1989 & 1991 & 1993 & 1995 & 1997 \\
\hline & & & & & & \\
59 & 55 & 60 & 52 & 40 & 62 & 62 \\
NA & 16 & 10 & 10 & 11 & 28 & 20 \\
NA & 12 & 18 & 24 & 15 & 25 & 27 \\
NA & 27 & 33 & 17 & 15 & 12 & 15 \\
& & & & & & \\
41 & 45 & 40 & 48 & 60 & 38 & 38
\end{tabular}

$\begin{array}{rrrrrrr}1 & 1 & 1 & 2 & 7 & 6 & 18 \\ 61 & 74 & 64 & 52 & 52 & 56 & 49 \\ 10 & 12 & 9 & 13 & 11 & 7 & 8 \\ 8 & 13 & 26 & 33 & 30 & 31 & 24\end{array}$

\begin{tabular}{lllllll}
25 & 32 & 19 & 27 & 23 & 33 & 32 \\
75 & 68 & 81 & 73 & 77 & 67 & 68 \\
\hline
\end{tabular}

Note: Data exclude supplemental / pension plans. Sums may not equal totals because of rounding. NA means data not available, and "---" means less than 0.5 percent.

Source: U.S. Department of Labor, Bureau of Labor Statistics, "Employee Benefits in Medium and Large Firms, 1985-1997" and unpublished data from the BLS for 1988? Figures. A comparable Employee Benefits Survey (EBS) was not conducted in 1987. The EBS sampling frame changed in 1988 to include smaller firms and more industries than before, so data for 1988 and later are not precisely comparable with previous years' tabulations. 


\section{Table 27A}

Provisions for Withdrawal of Employer Contributions Prior to Retirement, Disability or Termination of Employment: Savings and Thrift Plans,

\section{5-97}

Type of formula

\begin{tabular}{rrrrrrrrr}
\hline \multicolumn{8}{c}{ Percent of full-time participants } \\
1985 & 1986 & $1988 \dagger$ & 1988 & 1989 & 1991 & 1993 & 1995 & 1997 \\
\hline 20 & 18 & 29 & 28 & 29 & 50 & 51 & 43 & 48 \\
& & & & & & & & \\
80 & 82 & 71 & 72 & 71 & 50 & 47 & 43 & 52 \\
61 & 56 & 42 & 41 & 37 & 24 & 29 & 16 & 18 \\
30 & 19 & 15 & 14 & 17 & 16 & NA & NA & NA \\
30 & 37 & 26 & 25 & 18 & 8 & NA & NA & NA \\
& & & & & & & & \\
19 & 26 & 29 & 30 & 34 & 26 & 18 & 28 & 35 \\
14 & 21 & 21 & 22 & 27 & 17 & NA & NA & NA \\
3 & 5 & 6 & 7 & 7 & 9 & NA & NA & NA \\
\hline
\end{tabular}

*Commonly expressed hardship reasons include purchase or repair of primary residence, death or illness in the family, education of an immediately family member, or suddent uninsured loss.

tIn a few cases, the Bureau of Labor Statistics tabulated 1988 results using a sampling frame similar to that employed in previous years. For comparability purposes, these figures have been presented, where available, under columns headed "1988†", whereas tabulations from 1988 and 1989 otherwise employ the new, larger survey sampling frame.

Note: Data exclude supplemental pension plans. Sums may not equal totals because of rounding. NA means data not available, and "---" means less than 0.5 percent.

Source: U.S. Department of Labor, Bureau of Labor Statistics, "Employee Benefits in Medium and Large Firms, 1981-97." A comparable Employee Benefits Survey (EBS) was not conducted in 1987. The EBC sample frame changed in 1988 to include smaller firms and more industries than before, so data for 1988 and later are not precisely comparable with previous years' tabulations. 
Table 27B

Loan Provisions of 401(k) Plans: 1993-97

\begin{tabular}{rrr}
\hline \multicolumn{3}{c}{ Percent of full-time participants } \\
1993 & 1995 & 1997 \\
43 & 49 & \\
3 & 4 & 4 \\
39 & 44 & 44 \\
& & \\
56 & 46 & 40 \\
1 & 15 & 9 \\
\hline
\end{tabular}

*Many plants offer more than one form of cash distribution so sums of individual items exceed total.

Note: Data exclude supplemental pension plans. Sums may not equal totals because of rounding. NA means data not available, and "---" means less than 0.5 percent.

Source: U.S. Department of Labor, Bureau of Labor Statistics, Employee Benefits in Medium and Large Firms, 1985-97." A comparable Employee Benefits Survey (EBS) was not conducted in 1987. The EBC sample frame changed in 1988 to include smaller firms and more industries than before, so data for 1988 and later are not precisely comparable with previous years' tabulations. 


\section{Table 28}

Method of Distribution of Account at Retirement: Savings and Thrift Plans, 1985-97

\begin{tabular}{|c|c|c|c|c|c|c|c|c|}
\hline \multirow[b]{2}{*}{ Type of distribution } & \multicolumn{8}{|c|}{ Percent of full-time participants } \\
\hline & 1985 & 1986 & 1988 & 1989 & 1991 & 1993 & 1995 & 1997 \\
\hline Cash distribution* & 99 & 99 & 97 & 97 & 99 & NA & NA & NA \\
\hline Lifetime annuity & 29 & 25 & 25 & 28 & 30 & 30 & 17 & 25 \\
\hline Installments & 59 & 52 & 49 & 52 & 52 & 48 & 30 & 41 \\
\hline Lump sum & 99 & 98 & 95 & 96 & 99 & 98 & 85 & 91 \\
\hline
\end{tabular}

*Many plants offer more than one form of cash distribution so sums of individual items exceed total.

Note: Data exclude supplemental pension plans. Sums may not equal totals because of rounding. NA means data not available, and "---" means less than 0.5 percent.

Source: U.S. Department of Labor, Bureau of Labor Statistics, "Employee Benefits in Medium and Large Firms, 1985-97." A comparable Employee Benefits Survey (EBS) was not conducted in 1987. The EBC sample frame changed in 1988 to include smaller firms and more industries than before, so data for 1988 and later are not precisely comparable with previous years' tabulations. 
Table 29

Method of Distribution of Account at Retirement: 401(k) Plans: 1993-97

Type of distribution

Percent of full-time participants

$1993 \quad 1995$

1997

Cash distribution

Lifetime Annuity

Installments

34

21

27

Lump Sum

*Many plants offer more than one form of cash distribution so sums of individual items exceed total.

Note: Data exclude supplemental pension plans. Sums may not equal totals because of rounding. NA means data not available, and "---" means less than 0.5 percent.

Source: U.S. Department of Labor, Bureau of Labor Statistics, "Employee Benefits in Medium and Large Firms, 1985-97." A comparable Employee Benefits Survey (EBS) was not conducted in 1987. The EBC sample frame changed in 1988 to include smaller firms and more industries than before, so data for 1988 and later are not precisely comparable with previous years' tabulations. 
Table 30A

401(k) Plans: Investment Choices: 1993-97

\begin{tabular}{|c|c|c|c|c|c|c|}
\hline & \multicolumn{6}{|c|}{ Percent of full-time participants } \\
\hline & \multicolumn{2}{|c|}{1993} & \multicolumn{2}{|c|}{1995} & \multirow[t]{2}{*}{1997} & \multirow[b]{2}{*}{ Er } \\
\hline & $\mathrm{Ee}$ & $\mathrm{Er}$ & $\mathrm{Ee}$ & $\mathrm{Er} \mathrm{Ee}$ & & \\
\hline Investment Choices & & & & & & \\
\hline Employee permitted to & & & & & & \\
\hline choose investments: & 86 & 58 & & 6486 & & 65 \\
\hline $1-2$ choices & 11 & 8 & & 33 & & 2 \\
\hline 3 choices & 23 & 13 & & 1111 & & 8 \\
\hline 4 choices & 28 & 16 & & 1621 & & 14 \\
\hline$>5$ choices & 25 & 22 & & 3531 & & 24 \\
\hline
\end{tabular}

Note: Because of rounding, sums may not equal totals.

Source: U.S. Department of Labor, Bureau of Labor Statistics, "Employee Benefits in Medium and Large Firms, 1993-97." 


\section{Table 30B}

\section{Saving and Thrift Plans: Investment Choices, Investment Types, and Frequency of Investment Changes: 1989-97}

Investment Choices
Employee permitted to:
Choose Investments
$1-2$ choices
3 choices
4 choices
$>5$ choices

Types of Investment Choices Company stock Common stock

LT interest-bearing sec.

Diversified stock/bond

Guaranteed Investment

Money market

CD

Frequency of Investment Changes Total with choice allowed

- Anytime

- Specified No.

$1 / \mathrm{yr}$

$2-4 / \mathrm{yr}$

$>5 / y r$

- Other

\begin{tabular}{|c|c|c|c|c|c|c|c|c|c|}
\hline \multirow{2}{*}{\multicolumn{2}{|c|}{1989}} & \multirow{2}{*}{\multicolumn{2}{|c|}{1991}} & \multirow{2}{*}{\multicolumn{2}{|c|}{1993}} & \multirow{2}{*}{\multicolumn{2}{|c|}{1995}} & \multirow{2}{*}{\multicolumn{2}{|c|}{1997}} \\
\hline & & & & & & & & & \\
\hline $\mathrm{Ee}$ & $\mathrm{Er}$ & $\mathrm{Ee}$ & $\mathrm{Er}$ & $\mathrm{Ee}$ & $\mathrm{Er}$ & $\mathrm{Ee}$ & $\mathrm{Er}$ & $\mathrm{Ee}$ & $\mathrm{Er}$ \\
\hline 90 & 53 & 91 & 62 & 86 & 58 & 74 & 58 & 87 & 65 \\
\hline 25 & 22 & 15 & 16 & 12 & 7 & 3 & 3 & 2 & 2 \\
\hline 36 & 40 & 32 & 33 & 21 & 13 & 13 & 10 & 11 & 3 \\
\hline 23 & 20 & 29 & 25 & 30 & 17 & 21 & 13 & 21 & 14 \\
\hline 15 & 16 & 20 & 22 & 24 & 21 & 28 & 26 & 47 & 34 \\
\hline
\end{tabular}

$\begin{array}{cccccccccc}60 & 50 & 50 & 36 & 43 & 49 & 40 & 27 & 42 & 25 \\ 79 & 83 & 87 & 90 & 68 & 49 & 59 & 48 & 69 & 50 \\ 32 & 37 & 44 & 46 & 42 & 28 & 48 & 36 & 59 & 43 \\ 26 & 31 & 26 & 27 & 42 & 33 & 41 & 31 & 54 & 40 \\ 64 & 59 & 71 & 70 & 43 & 30 & 25 & 20 & 20 & 15 \\ 35 & 41 & 38 & 43 & 26 & 20 & 30 & 25 & 35 & 28 \\ 3 & 4 & 2 & 2 & 1 & 1 & 4 & 2 & 3 & 2\end{array}$

\begin{tabular}{llllcccccc} 
NA & NA & NA & NA & 86 & 58 & 74 & 58 & 87 & 65 \\
NA & NA & NA & NA & 25 & 19 & 38 & 32 & 47 & 36 \\
NA & NA & NA & NA & 56 & 37 & 31 & 21 & 32 & 22 \\
NA & NA & NA & NA & 4 & 2 & 3 & 2 & 2 & 1 \\
NA & NA & NA & NA & 44 & 28 & 20 & 15 & 22 & 17 \\
NA & NA & NA & NA & 8 & 6 & 8 & 4 & 8 & 4 \\
NA & NA & NA & NA & 19 & 2 & 6 & 5 & 7 & 6 \\
\hline
\end{tabular}

Note: Because of rounding, sums may not equal totals.

Source: U.S. Department of Labor, Bureau of Labor Statistics, "Employee Benefits in Medium and Large Firms, 1993-97." 
To order any of these papers in hard copy, see instructions at the end of this list. To subscribe to all NBER Working Papers or the papers in a single area, see instructions inside the back cover.

Number

7327

7328

7329

7330

7331

7332

7334

7335

7336

7337

7338

7339

7340

7341 $\underline{\text { Author(s) }}$

Mark McClellan

Douglas Staiger

John DiNardo

Mark P. Moore

Austan Goolsbee

Peter J. Klenow

Young-Hye Cho

Robert F. Engle

Young-Hye Cho

Robert F. Engle

Daniel S. Hamermesh

James L. Heckman

Rajesh K. Aggarwal

Andrew A. Samwick

Rajesh K. Aggarwal

Andrew A. Samwick

Richard Portes

Hélène Rey

Kathryn M. Dominguez

Jeffrey A. Frankel

Axel Börsch-Supan

Hylke Vandenbussche

Jozef Konings

Linda Springael

Robert F. Engle

Simone Manganelli $\underline{\text { Title }}$

$\underline{\text { Date }}$

The Quality of Health Care Providers

$8 / 99$

The Phillips Curve is Back? Using Panel Data to

Analyze the Relationship Between Unemployment and

Inflation in an Open Economy

Evidence on Learning and Network Externalities in the 9/99

Diffusion of Home Computers

Time-Varying Betas and Asymmetric Effect of News:

$9 / 99$

Empirical Analysis of Blue Chip Stocks

Modeling the Impacts of Market Activity on Bid-Ask

$9 / 99$

Spreads in the Option Market

The Changing Distribution of Job Satisfaction

$9 / 99$

Causal Parameters and Policy Analysis in Economics: $\quad$ 9/99

A Twentieth Century Retrospective

Performance Incentives Within Firms: The Effect of

$9 / 99$

Managerial Responsibility

Empire-Builders and Shirkers: Investment, Firm

$9 / 99$

Performance, and Managerial Incentives

The Determinants of Cross-Border Equity Flows

$9 / 99$

The Market Microstructure of Central Bank Intervention 9/99

No Single Currency Regime is Right for all Countries $\quad 9 / 99$ or at All Times

Incentive Effects of Social Security Under an Uncertain $\quad 9 / 99$ Disability Option

Import Diversion under European Antidumping Policy

$9 / 99$

CAViaR: Conditional Value at Risk By Quantile Regression

You can download these and other papers at the NBER Web site:

www.nber.org

Free searchable abstracts are also available at the site. 
To order any of these papers in hard copy, see instructions at the end of this list. To subscribe to all NBER Working Papers or the papers in a single area, see instructions inside the back cover.

\begin{tabular}{|c|c|c|c|}
\hline Number & Author(s) & Title & \\
\hline 7342 & $\begin{array}{l}\text { David C. King } \\
\text { Richard J. Zeckhauser }\end{array}$ & Congressional Vote Options & 9/99 \\
\hline 7343 & $\begin{array}{l}\text { Christina Paxson } \\
\text { Jane Waldfogel }\end{array}$ & Work, Welfare, and Child Maltreatment & $9 / 99$ \\
\hline 7344 & $\begin{array}{l}\text { Michael Hout } \\
\text { Harvey S. Rosen }\end{array}$ & Self-Employment, Family Background, and Race & 9/99 \\
\hline 7345 & $\begin{array}{l}\text { Jean O. Lanjouw } \\
\text { Mark Schankerman }\end{array}$ & $\begin{array}{l}\text { The Quality of Ideas: Measuring Innovation with } \\
\text { Multiple Indicators }\end{array}$ & 9/99 \\
\hline 7346 & $\begin{array}{l}\text { Geert Bekaert } \\
\text { Steven R. Grenadier }\end{array}$ & Stock and Bond Pricing in an Affine Economy & 9/99 \\
\hline 7347 & Thomas N. Hubbard & $\begin{array}{l}\text { How Wide Is the Scope of Hold-Up-Based Theories? } \\
\text { Contractual Form and Market Thickness in Trucking }\end{array}$ & 9/99 \\
\hline 7348 & Jonathan Gruber & $\begin{array}{l}\text { The Wealth of the Unemployed: Adequacy and } \\
\text { Implications for Unemployment Insurance }\end{array}$ & 9/99 \\
\hline 7349 & Edward P. Lazear & Educational Production & 9/99 \\
\hline 7350 & Tamim Bayoumi & $\begin{array}{l}\text { The Morning After: Explaining the Slowdown in } \\
\text { Japanese Growth in the } 1990 \mathrm{~s}\end{array}$ & 9/99 \\
\hline 7351 & $\begin{array}{l}\text { Taizo Motonishi } \\
\text { Hiroshi Yoshikawa }\end{array}$ & $\begin{array}{l}\text { Causes of the Long Stagnation of Japan during the } \\
\text { 1990's: Financial or Real? }\end{array}$ & 9/99 \\
\hline 7352 & $\begin{array}{l}\text { Daron Acemoglu } \\
\text { Robert Shimer }\end{array}$ & Productivity Gains From Unemployment Insurance & 9/99 \\
\hline 7353 & $\begin{array}{l}\text { Jeff Grogger } \\
\text { Charles Michalopoulos }\end{array}$ & Welfare Dynamics under Time Limits & $9 / 99$ \\
\hline 7354 & Roberto Rigobon & $\begin{array}{l}\text { On the Measurement of the International Propagation } \\
\text { of Shocks }\end{array}$ & 9/99 \\
\hline 7355 & $\begin{array}{l}\text { Ricardo J. Caballero } \\
\text { Mohamad L. Hammour }\end{array}$ & $\begin{array}{l}\text { The Cost of Recessions Revisited: A Reverse- } \\
\text { Liquidationist View }\end{array}$ & 9/99 \\
\hline 7356 & $\begin{array}{l}\text { Alec Ian Gershberg } \\
\text { Michael Grossman } \\
\text { Fred Goldman }\end{array}$ & $\begin{array}{l}\text { Competition and the Cost of Capital Revisited: Special } \\
\text { Authorities and Underwriters in the Market for Tax- } \\
\text { exempt Hospital Bonds }\end{array}$ & 9/99 \\
\hline
\end{tabular}

You can download these and other papers at the NBER Web site:

www.nber.org

Free searchable abstracts are also available at the site. 
To order any of these papers in hard copy, see instructions at the end of this list. To subscribe to all NBER Working Papers or the papers in a single area, see instructions inside the back cover.

\begin{tabular}{|c|c|}
\hline Number & $\underline{\text { Author(s) }}$ \\
\hline 7357 & Robert E. Lipsey \\
\hline 7358 & Vernon Henderson \\
\hline 7359 & $\begin{array}{l}\text { Iain Cockburn } \\
\text { Rebecca Henderson } \\
\text { Scott Stern }\end{array}$ \\
\hline 7360 & $\begin{array}{l}\text { Douglas Holtz-Eakin } \\
\text { John W. Phillips } \\
\text { Harvey S. Rosen }\end{array}$ \\
\hline 7361 & $\begin{array}{l}\text { Bong-Chan Kho } \\
\text { René M. Stulz }\end{array}$ \\
\hline 7362 & $\begin{array}{l}\text { Jagadeesh Gokhale } \\
\text { Laurence J. Kotlikoff }\end{array}$ \\
\hline 7363 & $\begin{array}{l}\text { Bruce D. Meyer } \\
\text { Dan T. Rosenbaum }\end{array}$ \\
\hline 7364 & $\begin{array}{l}\text { Dani Rodrik } \\
\text { Andrés Velasco }\end{array}$ \\
\hline 7365 & $\begin{array}{l}\text { Michael D. Bordo } \\
\text { Lars Jonung }\end{array}$ \\
\hline 7366 & Emmanuel Saez \\
\hline 7367 & Emmanuel Saez \\
\hline 7368 & $\begin{array}{l}\text { Alan L. Gustman } \\
\text { Thomas L. Steinmeier }\end{array}$ \\
\hline 7369 & $\begin{array}{l}\text { Wolfgang Keller } \\
\text { Arik Levinson }\end{array}$ \\
\hline 7370 & $\begin{array}{l}\text { Michael Baker } \\
\text { Gary Solon }\end{array}$ \\
\hline
\end{tabular}

Foreign Production by U.S. Firms and Parent Firm $9 / 99$ Employment

Marshall's Economies

The Diffusion of Science-Driven Drug Discovery:

Organizational Change in Pharmaceutical Research

Estate Taxes, Life Insurance, and Small Business

Banks, the IMF, and the Asian Crisis

$9 / 99$

Social Security's Treatment of Postwar Americans:

How Bad Can It Get?

Welfare, the Earned Income Tax Credit, and the Labor Supply of Single Mothers

Short-Term Capital Flows

$9 / 99$

The Future of EMU: What Does the History of Monetary Unions Tell Us?

Do Taxpayers Bunch at Kink Points?

The Effect of Marginal Tax Rates on Income: A Panel

$9 / 99$ Study of 'Bracket Creep'

What People Don't Know About Their Pensions $9 / 99$ and Social Security: An Analysis Using Linked Data From The Health and Retirement Study

Environmental Compliance Costs and Foreign Direct Investment Inflows to U.S. States

Earnings Dynamics and Inequality among Canadian Men, 1976-1992: Evidence from Longitudinal Income Tax Records

You can download these and other papers at the NBER Web site: 
To order any of these papers in hard copy, see instructions at the end of this list. To subscribe to all NBER Working Papers or the papers in a single area, see instructions inside the back cover.

$\begin{array}{ll}\text { Number } & \text { Author(s) } \\ 7371 & \begin{array}{l}\text { Michael Baker } \\ \text { Nicole M. Fortin }\end{array} \\ 7372 & \begin{array}{l}\text { B. Douglas Bernheim } \\ \text { Lorenzo Forni } \\ \text { Jagadeesh Gokhale } \\ \text { Laurence J. Kotlikoff }\end{array} \\ & \text { Paul A. David } \\ 7373 & \begin{array}{l}\text { Bronwyn H. Hall } \\ \text { Andrew A. Toole }\end{array} \\ & \begin{array}{l}\text { Peter Cappelli } \\ \text { David Neumark }\end{array} \\ 7374 & \text { Charles I. Jones } \\ 7375 & \\ 7376 & \text { Harrison Hong } \\ & \text { Jeremy C. Stein } \\ 7377 & \text { George Chacko } \\ & \text { Luis M. Viceira } \\ 7378 & \text { Bruce A. Blonigen } \\ & \text { Stephen E. Haynes } \\ & \text { Victor R. Fuchs } \\ 7380 & \text { Michael D. Hurd } \\ & \text { James P. Smith } \\ & \text { Olivia S. Mitchell } \\ & \end{array}$

Title

Date

Occupational Gender Composition and Wages in Canada: 9/99 1987-1988

The Adequacy of Life Insurance: Evidence from the $10 / 99$ Health and Retirement Survey

Is Public R\&D a Complement or Substitute for Private $10 / 99$ R\&D? A Review of the Econometric Evidence

Do "High Performance" Work Practices Improve $10 / 99$ Established-Level Outcomes?

Was an Industrial Revolution Inevitable?

Economic Growth Over the Very Long Run

Differences of Opinion, Rational Arbitrage

$10 / 99$ and Market Crashes

Dynamic Consumption and Portfolio Choice with

$10 / 99$ Stochastic Volatility in Incomplete Markets

Antidumping Investigators and the Pass-Through of

$10 / 99$

Exchange rates and Antidumping Duties

The Future of Health Economics

$10 / 99$

Anticipated and Actual Bequests

$10 / 99$

New Trends in Pension Benefit and

$10 / 99$

Retirement Provisions

Copies of the above working papers can be obtained for $\$ 10.00$ per copy (plus $\$ 10.00$ per order for shipping for all locations outside the continental U.S.) to Working Papers, NBER, 1050 Massachusetts Avenue, Cambridge, MA 02138-5398. Pre-payment is required on all orders and may be made by check or credit card. Checks should be made payable to the NBER and must be in dollars drawn on a U.S. bank. If paying by credit card, include the cardholder's name, account number, and expiration date. For all orders, please be sure to include your return address and telephone number. Working papers may also be ordered by telephone (868-3900), fax (617-868-2742), or email (orders@nber.org).

You can download these and other papers at the NBER Web site:

www.nber.org

Free searchable abstracts are also available at the site. 